\title{
Fit for Purpose and Fit for the Future? An Evaluation of the UK's New Flood Reinsurance Pool
}

\begin{abstract}
Flood Re is widely hailed as an innovative approach to disaster risk insurance. This paper offers a mixed-methods evaluation of the new pool, asking whether it is "fit for purpose" and "fit for the future". The investigation considers the roles of the public and private sectors, risk modelling and risk communication, technical underwriting, distributional aspects and the behavioural implications of Flood Re, particularly with regards to risk reduction and prevention. The paper concludes that the new pool is a transitional reinsurance arrangement that supports the private insurance market and secures affordability of flood insurance in the UK through premium subsidies. However, this approach is likely to come under pressure in the face of rising flood risk as it fails to incentivize flood risk management and risk reduction efforts.
\end{abstract}

Key Words: Flood Re, flood risk management, reinsurance 


\section{Fit for Purpose and Fit for the Future? An Evaluation of the UK's New Flood Reinsurance Pool}

\section{Introduction}

Natural disasters such as drought, flooding and wind storms cause significant human and economic losses, affecting communities, businesses and governments and hampering economic development and poverty reduction efforts. In many countries, such disasters are becoming more likely with climate change according to projections by the Intergovernmental Panel on Climate Change ("IPCC"). Moreover, the values at risk are also becoming even greater due to increasing population concentration and rising wealth, often in highly exposed coastal locations. These trends have re-intensified discussions among private insurers, governments and international organizations about the role of insurance in addressing disaster risks. The discourse follows two broad strands: reform of existing insurance schemes, such as in the United Kingdom and the United States; and the design of new schemes in countries without disaster insurance, including in developing countries (see, for example, Surminski and Oramas-Dorta, 2014). Such efforts are based on the understanding that insurance mechanisms offer a more effective way of addressing the costs of disasters than relying on post-disaster payments (see, for example, Hallegatte, 2014; and Brainard, 2008). The sharing of risks and the distribution of the costs of compensation make insurance an attractive disaster response mechanism, particularly for large catastrophic risks (Mechler et al., 2014), but remains underused in many parts of the world.

In countries that have disaster insurance, this tends to be arranged through the state or via a partnership approach between the public sector and private insurers, owing to the complex nature of disaster risks. The affordability and availability of disaster insurance can become a public policy goal, seeking to ensure that an economically efficient level of insurance is provided and accessible to those who need it. However, in many cases, governments face conflicting objectives and aims; in particular, being concerned with reducing public expenditure on flood losses, but at the same time remaining keen to offer a "helping hand" in times of flooding. If and how government intervenes in the flood insurance market therefore depends, at least in part, on a country's specific risk features, cultural approach to solidarity and responsibility, political will, as well as recent loss experiences (Kunreuther et.al. 2009).

There are many different ways in which disaster risk insurance can be supported by the government, ranging from direct premium subsidies to providing financial education.. Table 1 
shows how possible interventions can target the supply of insurance, the demand for insurance, or premium levels.

\section{Table 1. Public Disaster Risk Insurance Interventions with the Aim of Increasing Take-Up of Insurance}

\begin{tabular}{|c|c|}
\hline Target Area & Intervention Measure \\
\hline \multirow[t]{7}{*}{ Supply } & Set-up state-owned insurer \\
\hline & Provide reinsurance \\
\hline & Provide capital \\
\hline & Pay operational costs \\
\hline & Provide product development expertise and technical support \\
\hline & Promote co-insurance pool \\
\hline & Link to social safety nets and credit facilities \\
\hline \multirow[t]{5}{*}{ Premium Levels } & Regulate premiums by setting limits or tariffs \\
\hline & Regulate risk models used \\
\hline & Data collection, audit, management and financing (can lead to higher premiums) \\
\hline & Provide risk data to insurers (can also lead to higher premiums) \\
\hline & Reduce risk levels through better risk management \\
\hline \multirow[t]{7}{*}{ Demand } & Pay premiums in full or part \\
\hline & Offer vouchers for insurance \\
\hline & Offer incentives for insurance \\
\hline & Mandate insurance \\
\hline & Provide risk data / awareness campaigns \\
\hline & Financial education \\
\hline & Promote enabling environment via legal framework and consumer protection \\
\hline
\end{tabular}

Source: Vivid Economics et al., 2016.

The types of government intervention in disaster insurance markets vary significantly between countries, ranging from no insurance, to only private or fully public insurance. (Paudel 2012; Lamond and Penning-Rowsell 2914) For example, whilst French law requires certain kinds of insurance contracts to cover natural catastrophes and fixes an additional amount payable by the insured (Maccaferri et al., 2012), the UK government has focused on making flood insurance more affordable by improving reinsurance options for insurers through its flood reinsurance program, 'Flood Re'. Whilst the former can be considered a more 'public' approach to flood insurance, the latter has continued to rely predominantly on the private market.

One aspect that is growing in importance, but remains often overlooked in the public policy discourse, is the suitability of insurance mechanisms to cope with changing risk profiles. 
This is particularly relevant in the face of rising disaster costs due to socio-economic factors and climate change, which can pose a threat to future insurability.

These trends can negatively impact the business model of the insurance industry itself, possibly making insurance unavailable or unaffordable. Currently, the industry's best defence against this is the one-year contract relationship with clients, which does not require an assessment of long-term risk, and offers flexibility to amend and adjust price coverage on an annual basis. However, this is only a short-term defence against rising risk. If significant efforts are not taken to reduce risk by increasing resilience, costs will continue to rise and insurers may stop offering climate change-related insurance products, as noted by the UK's regulator PRA (Prudential Regulation Authority, 2015); indeed, adaptation could feasibly become a prerequisite to receiving insurance (Golnaraghi et al., 2016).

Purchasing an insurance product can influence the behaviour of those at risk. This can either be in a moral hazard ${ }^{1}$ context, where insurance can lead to more risky behaviour, or as an incentive, where insurance can trigger risk reduction investments or the implementation of prevention measures (see, for example, Kunreuther, 1996; and Kunreuther and Michel-Kerjan, 2009). Despite a renewed interest in risk reduction by policy makers and regulators in their quest to find ways to use insurance in order to insulate public finances from the financial impact of natural disasters (for a summary, see Golnaraghi et al., 2016; Prudential Regulation Authority, 2015; and European Commission, 2013)in practice most disaster insurance schemes are not designed or operated with prevention in mind. (Surminski and Hudson, 2017; and Surminski et al., 2015). This raises questions about their suitability and effectiveness.

These challenges are also evident in the UK, which has a long tradition of private flood insurance. Flooding is recognized as the most common and costliest kind of natural disasterCommittee on Climate Change, 2016) and is listed as a major risk on England's National Risk Register (Cabinet Office, 2015). While the recent flood loss trends in the UK are largely due to socio-economic factors, such as continuing development in exposed areas, climate change is expected to exacerbate these impacts (IPCC, 2013). Indeed, the UK Climate Change Risk Assessment (CCRA) 2017 has identified flood risk management as a priority area for action, as

\footnotetext{
${ }^{1}$ Moral hazard occurs when a member of the party acts conversely to the principles set out in an agreement between those parties. For example in an insurance contract, the individuals' motives and behaviour to prevent loss may be reduced if financially protected through a policy, thus resulting in an increased probability of loss. For more detail on moral hazard, please see Arrow (1968) and Pauly (1968). This can affect governments, where the existence of an insurance scheme may reduce the urgency to prevent and reduce risks, or at the insured level, where the purchase of insurance may lead to a false sense of security.
} 
flood risks are projected to increase significantly across the UK throughout this century (Committee on Climate Change, 2016).

Against this backdrop of growing flood risk a new reinsurance pool was created by government and industry: : Flood Re, a not-for profit reinsurance pool owned and operated by the insurance industry, developed by industry and government, established through the Water Act 2014 and launched in 2016. It has been presented by industry and government as an “ innovative way to ensure the availability and affordability of flood insurance, without placing unsustainable costs on wider policyholders and the taxpayer" (DEFRA, 2013). The pool is designed as a temporary support measure for those high-risk properties that may face rising insurance premiums in a competitive market. Presented as a "cushion" to smooth an eventual transition to risk-reflective pricing, it remains unclear if and how Flood Re will achieve this in the face of rising flood risk, especially because in its current set-up, it does not provide any direct means to encourage risk reducing behaviour (Surminski and Eldridge, 2015; and Hjalmarsson and Davey, 2016).

This raises the question whether Flood Re is fit for purpose and fit for the future, and what lessons can be drawn for governments seeking to navigate between public policy and private market solutions to address affordability and availability of flood insurance.

As Flood Re only came into operation in April 2016, there is very limited quantitative evidence, while for the broader flood insurance market in the UK many of the metrics needed for an assessment are not publicly available. This shortfall can be addressed by applying a mixedmethods approach to the evaluation, as outlined in Section 2. After a brief reflection on the history of flood insurance in the UK and the justification for Flood Re (Section 3), this paper assesses the pool against five broad parameters: (i) the contribution to technical risk cost modelling and risk communication, (ii) the roles of the public and private sectors, (iii) whether insurance incentivizes risk reduction by policyholders, (iv) how it contributes to take-up rates of flood insurance, and (v) how insurance distributes the costs of disaster events (Section 4). This leads to an overall evaluation of the "fitness for purpose" and "fitness for the future" of Flood Re with some recommendations (Section 5), and a discussion of possible implications for other countries (Section 6).

\section{A Brief Reflection on Methods and Data}

The literature provides many assessment criteria for insurance mechanisms including for those created through public policy interventions. Key aspects of these assessment criteria are 
availability of cover for the insured, affordability of cover for the insured, whether the mechanism is financially sustainable (i.e. whether it is able to pay claims and stay solvent), and whether the mechanism is commercially viable for insurers participating in it, provided private sector involvement is required (Surminski and Hudson, 2017; and Surminski, 2014).

Traditionally, the focus has been on classic supply and demand questions, exploring the cost-effectiveness of an insurance scheme for any given policyholder, as well as the market-level efficiency in meeting as large a proportion of the potential demand as possible. In addition, given that public funding is sometimes used to support insurance with an explicit or implicit justification based on providing a public good, cost-effectiveness must take into account whether this funding is achieving good value for money. Finally, there is the longer-term financial sustainability of an insurance mechanism in the face of risk.

These aspects provide a starting point for determining whether Flood Re is fit for purpose, based on its stated objectives of securing affordable and available flood insurance. The main criteria to look at are price of cover before and after the intervention, and any evidence for level of penetration and take-up before and after. Many of those metrics still remain unclear for Flood Re due to its nascent character and the private sector underwriting that is underpinning it. As Flood Re only commenced operation in April 2016, there is very limited data to underpin an assessment of its effectiveness, impact and policy consequences. For instance, analysing the future behaviour of insurers faces data limitations as the risk models that are commonly used by insurers for rate setting are sensitive business information and not freely accessible.

Furthermore, such an evaluation is too narrow, as it does not reflect on the influence of flood insurance on risk reduction efforts, which is becoming increasingly important for future insurability and societal resilience. Therefore, the paper also considers additional factors that relate to Flood Re's role in risk reduction. This is based on the understanding that insurance, or risk transfer in general, can boost risk reduction if designed and structured accordingly, which in turn can secure future affordability and availability of cover. (for an overview see Hudson 2017). Various metrics for assessing how insurance promotes risk reduction/prevention have been proposed in the literature (including Crichton, 2008; Paudel, 2012; Surminski and Oramas-Dorta, 2014; and Surminski and Eldridge, 2015), exploring how risk pricing may encourage the reduction of exposure and lead to lower damage costs (Kunreuther, 1996; and Di Falco et al., 2014), how risk information and other measures influence the behaviour of policyholders, how insurance directly promotes actions by policyholders, and how insurance directly or indirectly affects actions by third parties (such as the government). 
This paper deploys a mix of quantitative and qualitative metrics and criteria, based on available data analysis, stakeholder interviews and a review of existing literature. ${ }^{2}$ Taken as a whole, and given likely inconsistencies in information availability, this broad set of metrics has the advantage of providing a robust picture of Flood Re as a public policy intervention, allowing for comparison with other intervention types.

\section{Flood Insurance in the UK - the Pathway to Flood Re}

The UK has a long tradition of insurance provision, dating back to the 17 th century with Lloyds of London starting the commercial underwriting of cargo ships. This partly explains the wide acceptance and utilization of insurance to address a wide range of risks, including flooding.

Historically, the provision of flood insurance in the UK has been addressed through a series of informal arrangements reached between the government and the insurance industry, but the underwriting has always been provided on a purely private sector basis. The first of these was the 1961 Gentleman's Agreement, which followed a number of significant flooding events such as the 1953 East Coast floods (which ultimately resulted in 308 deaths). These events exposed a low level of flood insurance penetration (Penning-Rowsell et al., 2014), and triggered efforts by government to increase usage of flood insurance. Against the threat of nationalization (Surminski and Eldridge, 2015), the industry reached an agreement with the government based on a commitment from the insurance industry to provide affordable insurance against flooding, if requested to do so, for all private dwellings which were permanently occupied. Because flood risk at that time could not be effectively determined per household (for example, through data mapping), this involved cross-subsidization between low and high risk homes. Although the Gentleman's Agreement was initially unsuccessful in increasing flood insurance penetration (due to the caveat that flood insurance need only be provided when requested by the policyholder), it was more successful once the Building Societies Association made insurance coverage a prerequisite to obtaining mortgage financing in the 1970s (Penning-Rowsell et al., 2014).

\footnotetext{
2 The analysis included eight interviews with representatives of the insurance and reinsurance industry in the UK, and two interviews with flood insurance experts from the public sector, including the Department for Environment, Food and Rural Affairs (DEFRA). Further investigations took place as part of the ENHANCE analysis of the new Flood Re pool, which included stakeholder workshops in 2014, 2015, and 2016; see Surminski and Eldridge (2015); Jenkins et al. (2017); Crick et al. (2016); and Surminski and Hudson (2017).
} 
The Gentleman's Agreement was ultimately challenged by the Association of British Insurers ("ABI") in the wake of rising flood losses. In 2001, the ABI issued a memorandum to the government stating that ABI member companies would only maintain insurance provision after flood events if there was greater investment in flood risk reduction measures by the government in flood prone areas, better data provision and stricter planning regulation. Commentators such as Penning-Rowsell et al. (2014) attribute this to a new found sense of confidence in the insurance industry following positive feedback for its response to the flooding of 10,000 homes in the UK in 2000, and the losses the insurance industry suffered as a result of such flooding. Other commentators see these events as merely being a "window of opportunity" for change (Kingdon, 1995). Ultimately, this led to a series of Statement(s) of Principle between the insurance industry and the government, all based on a mutual interest in a functioning private flood insurance system (Surminski and Eldridge, 2015):

- The 2002 Statement of Principles on the Provision of Flood Insurance, which provided for flood coverage generally up to a risk level of 1:75 return period (1.3 percent) for households and small businesses as part of their building and/or contents cover.

- The 2005 updated version of the Statement of Principles, which continued the above commitment to 2008. For households exceeding the 1:75 risk level without adopting flood defense measures, insurers could not "guarantee to maintain cover".

- The 2008 Revised Statement of Principles on the Provision of Flood Insurance, which also continued the above commitment to 2013, but did not apply to any new property built after 1 January 2009. This has since been carried over into Flood Re. In turn, the government agreed to continue investing in flood risk mitigation.

Although the Statement(s) of Principles have been considered a success in terms of expanding flood insurance penetration (reaching approximately 95 percent according to HM Government, 2016), insurers have raised concerns about market price distortions in the form of underpriced flood insurance for houses in high flood-risk areas, with the ABI estimating that 78 percent of policyholders were paying a premium that does not fully reflect their flood risk (DEFRA, 2014). As a result, households in low flood-risk areas were cross-subsidizing those in high-risk areas — as illustrated in Figure 1: 
Figure 1. Cross-Subsidy for High-Risk Households

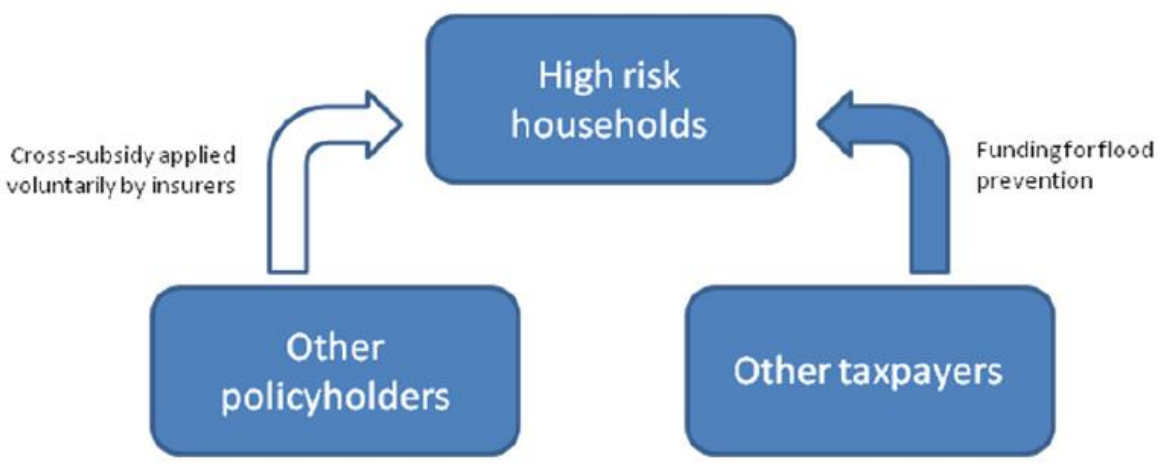

Source: DEFRA, 2013.

However, recent improvements in risk analysis technologies such as data mapping led to growing concerns that flood insurance would become unaffordable for those in high flood-risk areas once their risk could be properly ascertained by insurers (Oxera, 2015). As such, between 2010 and 2013, the insurance industry and government took steps to reach an understanding on how to replace the Statement(s) of Principles. Negotiations between the government and insurers continued through 2012 (Edmonds, 2016). A key point in the debate was the government's aversion to taking on any financial risk of an insurance scheme or flood damages, an example of which was delivered by the Parliamentary Under-Secretary of State for Environment, Food and Rural Affairs, who stated that money would be better spent delivering defences rather than subsidizing insurance premiums - a position that appeared increasingly at odds with theproclaimed government aimof universal availability of coverage and affordability (Hansard, 2011).

After a public consultation on four different flood insurance mechanisms, the government selected Flood Re, the option that had initially been proposed by the insurance industry. Figure 2 outlines the pool concept that was presented jointly by the government and the ABI. 
Figure 2. Pool Concept for Flood Re

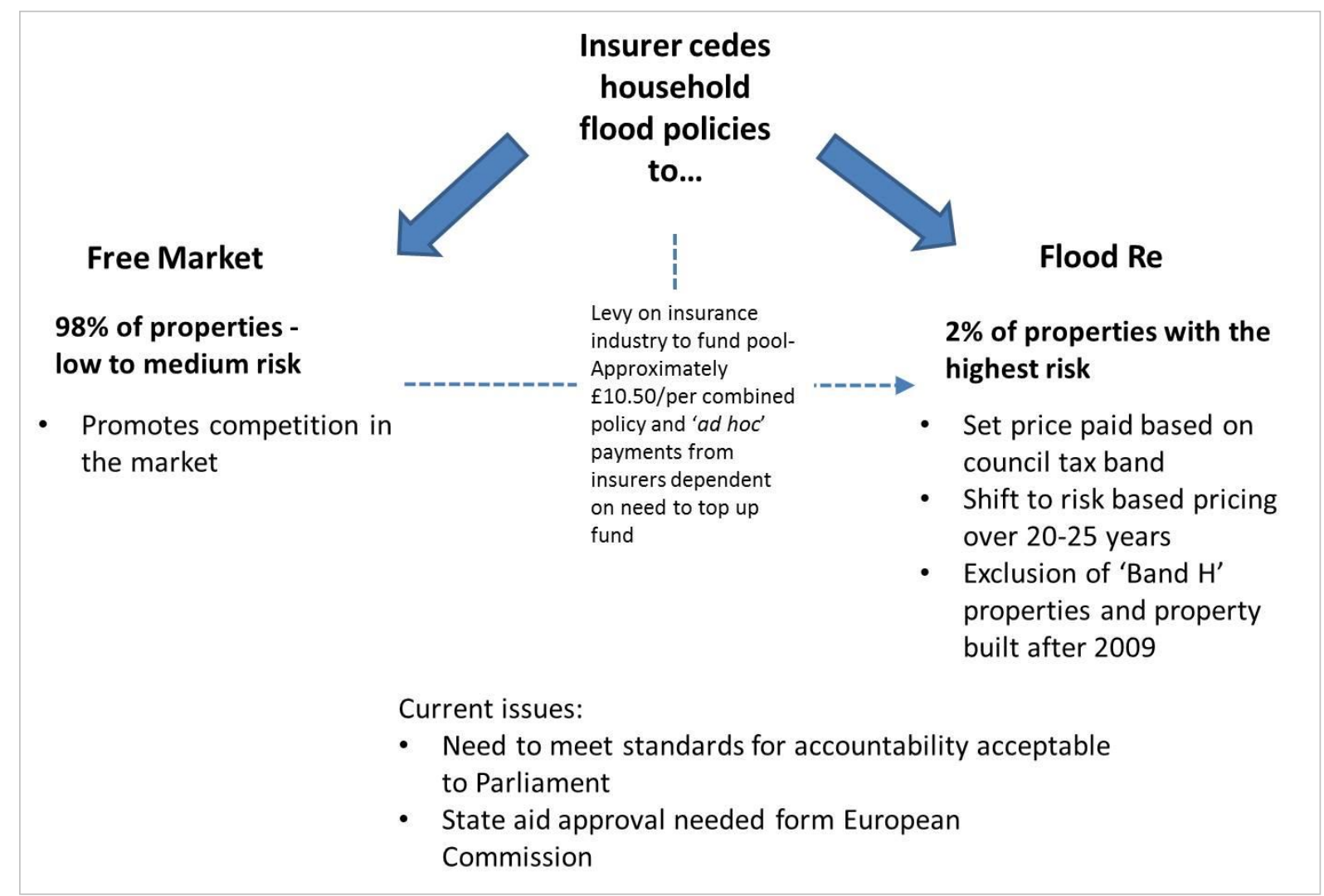

Source: Detail taken from the Environment, Flood and Rural Affairs Committee (House of Commons, 2013) on 26th February 2013 for the Flood Re insurance proposal and Flood Re Memorandum of Understanding (DEFRA and ABI, 2013).

Flood Re seeks to satisfy the dual objectives of market autonomy and insurance affordability. The main idea is a continuation of the provision for households under low to normal risk with standard insurance, while giving insurers the option to cede any properties to Flood Re at a highly discounted price. The subsidy for the latter is claimed from a levy taken from all insurers according to their overall home insurance market share, which is expected to be passed on to all policyholders through a surcharge on their insurance policy (Aviva PLC, 2016a), which mirrors the cross-subsidization that occurred under the Statement(s) of Principles (Diacon, 2013). The levy is estimated to be $£ 10.50$ per policy. By limiting the insurers’ risk in this way, the logic goes that the insurer can in turn limit the premiums they charge to policyholders in high flood-risk areas (although this remains at their discretion). Furthermore, Flood Re charges insurers an excess of $£ 250$, which is expected to limit the excess that insurers charge their clients. (Flood Re, 2016a). The levy and premiums are only sufficient to cover the costs associated with a 1 in 200 year event (i.e. flooding six times the severity of the 2007 floods). This is the regulatory capital limit set by the Prudential Regulation Authority. In accordance with current 
actuarial modelling, this would amount to approximately $£ 2.5$ billion (Diacon, 2013). In the event that post-flood claims exceed Flood Re's reserves, Flood Re can make a levy II call on insurers for additional funding. Importantly, there is no formal public back-up mechanism should Flood Re become insolvent, however, there is the expectation that the government may step in to provide financial support if levy II should still be inadequate to ensure Flood Re's solvency.

The flood premiums offered by Flood Re are fixed, based on council tax banding. Council tax is a tax levied on domestic property and collected by local councils. The rate of council tax differs by property tax bands, which in England are based on the price the property would have sold for on the open market on 1 April 1991 (Valuation Office Agency, 2017). For example, band A properties are those which would have sold for up to $£ 40,000$ (Valuation Office Agency, 2017). As such, property valuations do not represent actual wealth, and there have long been concerns that this leads to unfair outcomes. For example, there have been cases of million pound properties paying roughly the same council tax as properties of significantly lesser value (Brignall, 2012).

The premium thresholds for 2016 are provided in Figure 3 below:

Figure 3. Flood Re Premium Thresholds for 2016

\begin{tabular}{|c|c|c|c|c|c|c|c|c|}
\hline $\begin{array}{l}\text { Property tax band in } \\
\text { England and Scotland }\end{array}$ & A & B & C & D & E & $\mathbf{F}$ & G & $\mathrm{H}$ \\
\hline Property tax band in Wales & $\mathrm{A} \& \mathrm{~B}$ & C & D & $\mathbf{E}$ & $\mathbf{F}$ & G & $\mathrm{H}$ & I \\
\hline $\begin{array}{l}\text { Flood Re category in } \\
\text { Northern Ireland }\end{array}$ & 1 & 2 & 3 & 4 & 5 & 6 & 7 & 8 \\
\hline Building only - net & $€ 132$ & $€ 132$ & $€ 148$ & $€ 168$ & $€ 199$ & $€ 260$ & $€ 334$ & $€ 800$ \\
\hline Contents only - net & $€ 78$ & $€ 78$ & $€ 98$ & $€ 108$ & $€ 131$ & $€ 148$ & $€ 206$ & $€ 400$ \\
\hline Combined-net & $€ 210$ & $€ 210$ & $€ 246$ & $€ 276$ & $€ 330$ & $€ 408$ & $€ 540$ & $€ 1200$ \\
\hline
\end{tabular}

Source: Flood Re, 2016b.

The final structure and mode of operation of Flood Re is illustrated in Figure 4. 
Figure 4. Structure and Mode of Operation of Flood Re

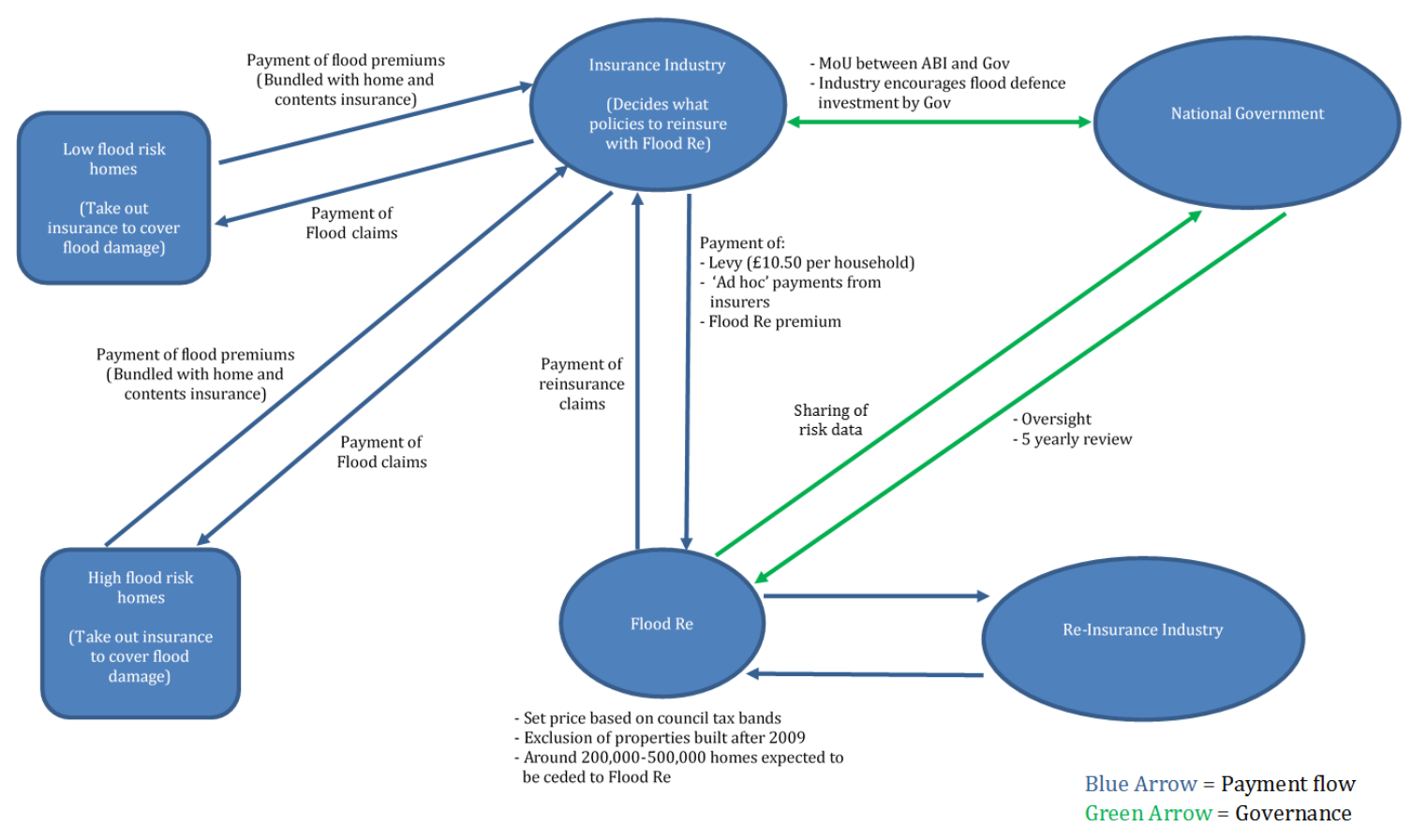

Source: Crick et al., 2016.

As it is a reinsurance scheme, consumers have no direct interaction with Flood Re; instead, private insurers remain the sole source of flood insurance in the market and it is left to their discretion whether or not to cede into the new pool. This has attracted some criticism for lacking transparency and hindering opportunities for the sharing of risk information (including measures on what risk reduction measures they can adopt to reduce their overall flooding risk) (Surminski and Eldridge, 2015).

Insurance providers representing 85 percent of the flood insurance market have so far agreed to participate in Flood Re (Insurance Newslink, 2016).

Preliminary market data suggests that insurers are applying a degree of selectivity regarding which policies they cede to Flood Re. Specifically, they have tended not to opt low flood-risk households into Flood Re (e.g. Direct Line Insurance PLC, 2016). This makes sense from an economic perspective; if an insurer can offer flood insurance at a rate that is more competitive than the premium they are required to pay under Flood Re, there is no incentive to cede the relevant policy. This is reflected in Figure 5 below: 
Figure 5. Flood Re pricing approach

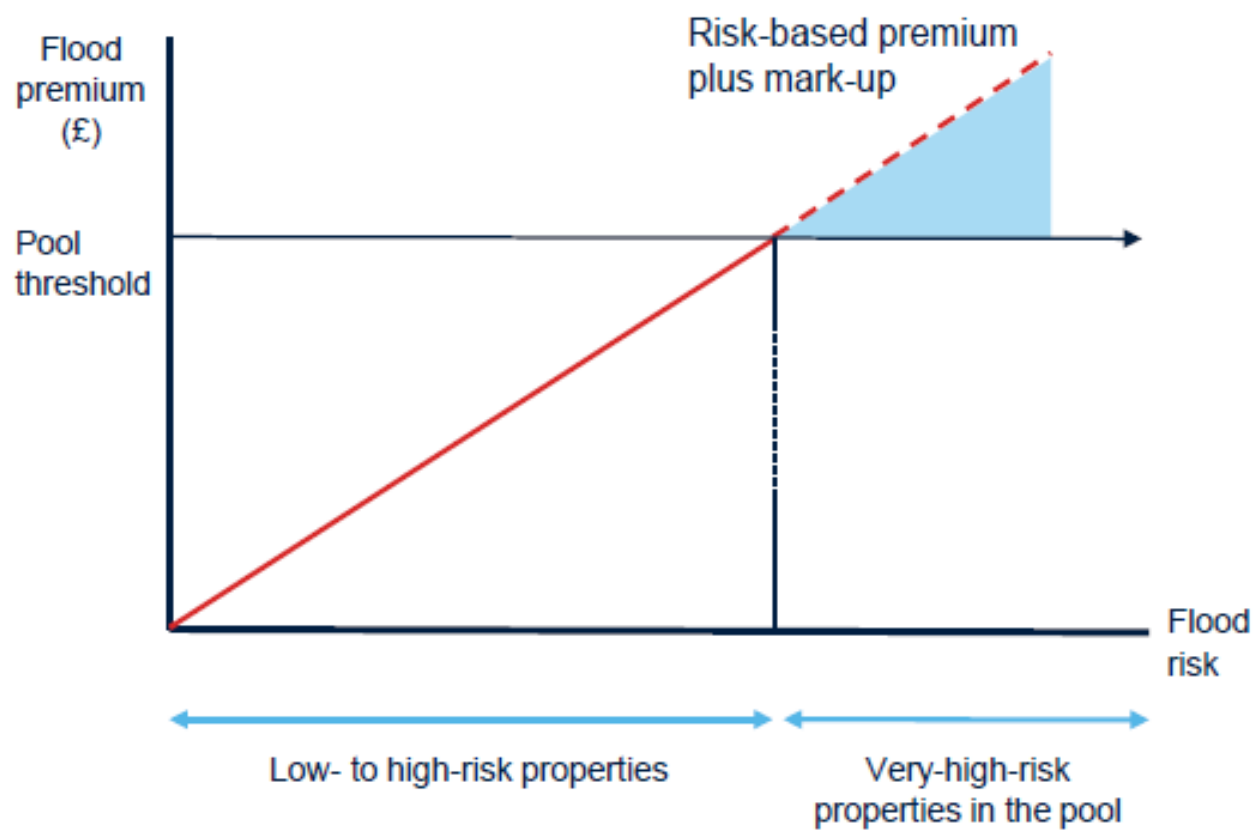

Source: Oxera, 2015.

\section{Assessing Flood Re Against Five Parameters}

\subsection{Roles of the Public and Private Sector}

Flood insurance in the UK is unique amongst most other national schemes as it is provided entirely by the private market. Flood Re, despite being a public policy intervention, does not change this. The pool is an addition to the standard home insurance market rather than a replacement (Horn and McShane, 2015). It does not replace private insurance cover but is expected to encourage private carriers to write affordable flood insurance policies for high-risk properties, as the pool offers insurers a low-cost option to offset the costs of property insurance claims for flood damage (BMI Research, 2016).

There is no direct financial liability for government, unlike in many other pools and disaster insurance schemes, where government picks up losses beyond a pre-defined threshold. Throughout the negotiations between industry and government this point was highly controversial, with the ABI calling for government to take on a clear financial obligation, and government refusing to commit. There remains the possibility of government stepping in as an emergency bail-out should Flood Re fail, but as the pool has to comply with standard solvency 
regulation and is buying commercial reinsurance cover this risk is considered to be low by the government (DEFRA, 2013).

Government plays a key role in determining the rules of operation and monitoring as well as possibly adjusting the remit and scope of the pool. Furthermore, Flood Re, being created by public law, has direct accountability to parliament, with the Secretary of State in an oversight function. Flood Re Limited, which has been designated as the scheme administrator under The Flood Reinsurance (Scheme and Scheme Administrator Designation) Regulations 2015, is required to review Flood Re's finances at least every five years. The report is provided to the Secretary of State who must consider any recommendations made by the scheme administrator in the report, including recommendations relating to the levy and premium threshold levels. This review process is contained in The Flood Reinsurance (Scheme Funding and Administration) Regulations 2015. This arrangement can create some governance confusion - with the government treating Flood $\mathrm{Re}$ as a quasi-public body, subject to public procurement processes, while Flood Re appears to take a much more commercially oriented approach to reinsurance purchasing and operations (this observation is based on personal communication from DEFRA and Flood Re). It is important to remember that Flood Re was developed and proposed by the industry, with companies calling for government intervention.

Both the previous Statement(s) of Principles and Flood Re can be described as publicprivate partnerships (Surminski, 2014). In line with the agreement set out under the Statement(s) of Principles, government remains responsible for flood risk management activities such as the construction of flood defences and the regulation of water utilities who construct and maintain sewers. It also attempts to reduce risk by providing grants to victims of floods, such as following Storm Desmond in 2015 (HM Government, 2016). In 2005, the Statement of Principles listed the obligations of the government as "reducing the probability of flooding in the UK; at least maintaining investment in flood management each year and discussing future funding taking into account climate change; implementing reforms to the land use planning system; communicating flood risk effectively and providing more detailed higher quality flood risk information and developing an integrated approach to urban drainage" (ABI, 2005). The fulfilment of these policy demands has been subject to debate - particularly with regards to investment levels and success of the planning system. For example, the ABI has been critical of reductions in investment in flood defences (ABI, 2010) and a lack of clear lines of responsibility for flood defences (Kenning, 2012). Similarly, the ABI has expressed concern in the past with the approval of new developments despite the Environment Agency advising against them because of their flood risk (ABI, 2009a). Flood Re is less specific on these broader roles of government, 
but in its first 'Transition Plan' publication, the pool itself acknowledges that it does not have strong direct levers to influence flood resilient decisions due to its design and that its success does depend on government action in flood risk management (Flood Re 2016b).

The roles of the public and private sectors are summarized in Table 2 below.

Table 2. The Roles of the Public and Private Sectors

\begin{tabular}{|c|c|}
\hline $\begin{array}{l}\text { How are duties split } \\
\text { between the public } \\
\text { and private sectors? }\end{array}$ & $\begin{array}{l}\text { - Insurance industry provides primary cover. } \\
\text { - } \quad \text { Reinsurance market and Flood Re provide reinsurance. } \\
\text { - } \text { Flood Re is a not-for-profit entity, created by statutory law and responsible to } \\
\text { - } \quad \text { Government has no financial obligations/liability under Flood Re arrangement. } \\
\text { - Government is responsible for flood risk management and flood risk maps, } \\
\text { delivered through the Environment Agency. } \\
\text { Other public bodies share that responsibility, including local authorities and } \\
\text { regional boards. }\end{array}$ \\
\hline $\begin{array}{l}\text { How much of the } \\
\text { risk does the public } \\
\text { sector bear? }\end{array}$ & $\begin{array}{l}\text { - } \quad \text { No formal "insurer of last resort" arrangement. } \\
\text { - Claims to Flood Re covered by a levy charged to insurance companies based on } \\
\text { their market share (not on their use of Flood Re). } \\
\text { - Expected that levy is passed on to all insurance customers - replacing previous } \\
\text { cross-subsidy. } \\
\text { - Flood Re is buying commercial reinsurance. }\end{array}$ \\
\hline $\begin{array}{l}\text { At what point does } \\
\text { the public sector } \\
\text { begin to cover a } \\
\text { risk? }\end{array}$ & $\begin{array}{l}\text { - } \\
\text { - } \quad \text { Possibility of public bail-out if Flood Re fails, but no agreed cut-off point. } \\
\text { - If insufficiently funded, Flood Re can make Levy II call for increased contribution } \\
\text { from insurers. }\end{array}$ \\
\hline $\begin{array}{l}\text { How does the } \\
\text { program encourage } \\
\text { or discourage } \\
\text { private market } \\
\text { involvement in the } \\
\text { market? }\end{array}$ & $\begin{array}{l}\text { - Insurance market is purely private - Flood Re can only work if there is a functioning } \\
\text { private insurance market. } \\
\text { - Aim is to encourage flood insurance provision at affordable rate - impact on } \\
\text { competition is unclear, but expected to be positive as Flood Re has been developed } \\
\text { by the industry. } \\
\text { - Complements private reinsurance provision, Flood Re buys own commercial } \\
\text { reinsurance cover. } \\
\text { - Allows insurers to better offset costs (BMI Research, 2016). }\end{array}$ \\
\hline
\end{tabular}

\subsection{Take-Up Rates of Flood Insurance}

As there is still very limited data on the usage of Flood Re, the following assessment looks at overall take-up rates of flood insurance in the UK. This appears to be very high, with two separate estimates in 2016 suggesting the take-up rate for homeowners is 95 percent (HM Government, 2016) and 98 percent (Flood Re, 2016b). The rate remains similar for homes in low 
and high flood risk areas (Flood Re, 2016b). The take up rate for renters is lower, reaching 55 percent in high-risk areas (Flood Re, 2016b). However, earlier statistics suggest that up to 35 percent of very-low income households have no insurance of any kind (ABI, 2007). Furthermore, recent $A B I$ statistics suggest take-up rates are only 76 percent and 64 percent for contents and building insurance respectively (ABI, 2015). It is unclear which set of figures provides a more accurate portrayal. Importantly, those figures are not specifically for flood risk, but for home insurance in general, due to the bundled nature of cover.

There are two reasons why take-up rates of flood insurance are so high in the UK: (i) flood insurance is generally included as standard with building and contents insurance, meaning that customers do not choose to get flood insurance, but automatically receive it along with their standard cover; and (ii) basic structural flood insurance is a pre-requisite for prospective homeowners obtaining a mortgage (HM Government, 2016). As such, the availability of flood insurance tends to not be an issue other than for a few properties at high risk that have been repeatedly flooded; instead, the main concern for low income households is its affordability (DEFRA, 2015).

In this context, Flood Re is unlikely to have a significant impact on overall take-up rates of flood insurance, but should address those cases where high prices or lack of available cover might lead to non-purchase of insurance. In a worst case scenario (i.e. the Statement of Principles was not renewed), DEFRA estimated that approximately 28,000 households could experience insurance price rises in excess of $5 \%$ of their income (DEFRA, 2014). Furthermore, flood victims of the 2013/14 floods often faced "impossible" insurance premium increases or could not find insurers willing to provide coverage (Ellis, 2014). Per Hoban (2016), the combined effect of increased flooding risk and improved data collection "...led to higher premiums and five figure excesses for those at higher risk of flooding".

One area where take-up rates are of concern are small and medium sized businesses (SMEs). However, SMEs are not covered under Flood Re, with the caveat that government may reconsider this decision if availability and affordability of SME cover becomes a growing issue. For the moment, industry and government have concluded that the evidence suggests that SMEs' difficulties with flood insurance are localized problems and would not justify a country wide solution (Committee on Climate Change, 2016).

The take-up rate of flood insurance is summarized in Table 3 below. 
Table 3. Take-Up Rates of Flood Insurance

\begin{tabular}{|c|c|}
\hline $\begin{array}{l}\text { What are take-up rates for } \\
\text { insurance? }\end{array}$ & $\begin{array}{l}\text { For Homeowners } \\
\text { - } \quad 95 \% \text { (HM Government, 2016). } \\
\text { - } 98 \% \text { (Flood Re, 2016b). } \\
\text { For Renters } \\
\text { - } \quad 55 \% \text { in high-risk areas (Flood Re, 2016b). } \\
\text { - } \quad \text { However, see ABI (2007) statistics, which suggest } \\
\quad 35 \% \text { of people in very-low income households have } \\
\text { no insurance of any kind. }\end{array}$ \\
\hline Why are they at this level? & $\begin{array}{l}\text { - } \quad \text { Bundled with other insurance (HM Government, } \\
\text { 2016). } \\
\text { - } \quad \text { Pre-requisite for getting a mortgage (HM } \\
\text { Government, 2016; and Flood Re, 2016b). }\end{array}$ \\
\hline What are the contributing factors? & $\begin{array}{l}\text { - Main concern for low income households is the } \\
\text { affordability of insurance rather than its availability } \\
\text { (DEFRA, 2015). }\end{array}$ \\
\hline $\begin{array}{l}\text { How does disaster aid and/or } \\
\text { investment in loss reduction } \\
\text { measures influence take-up rates of } \\
\text { insurance? }\end{array}$ & $\begin{array}{l}\text { - Take-up rates historically very high, therefore only } \\
\text { limited influence in the short term }\end{array}$ \\
\hline $\begin{array}{l}\text { How is insurance purchase handled } \\
\text { for those not able or willing to pay } \\
\text { for coverage? }\end{array}$ & $\begin{array}{l}\text { - Flood Re designed to make insurance affordable. } \\
\text { Not handled for those still unwilling to purchase it. }\end{array}$ \\
\hline $\begin{array}{l}\text { How are take-up rates influenced by } \\
\text { other financing mechanisms and } \\
\text { other governmental programs, such } \\
\text { as provision of disaster aid or } \\
\text { hazard mitigation programs? }\end{array}$ & $\begin{array}{l}\text { - This does not seem an issue, as shown by high } \\
\text { penetration rates. }\end{array}$ \\
\hline
\end{tabular}

\subsection{Distribution of the Costs of Catastrophes}

According to official impact assessments the move from the Statement of Principles to Flood Re should not create a significant shift in how the costs of flooding is distributed as the pool only formalizes the previous degree of cross-subsidization from low-risk properties to highrisk properties (Defra 2014). Policies ceded to Flood Re from the $£ 180 \mathrm{~m}$ flood levy paid through the $£ 10.50$ surcharge by all policyholders. This is meant to replace the cross-subsidization that existed under the Statement of Principles. It is expected that insurers will pass on the subsidized reinsurance price when making underwriting decisions, which could also benefit those not ceded to Flood Re. For example, leading insurer Aviva has announced plans to remove any additional flood excesses on existing customers' policies at renewal, even if it is not transferred to Flood Re 
(Aviva PLC, 2016b). However, it is not clear how transparent this (or the estimated additional charge of $£ 10.50$ per policy) is being made for policyholders.

The role of subsidies in addressing the equity aspects of flood insurance has been discussed for the UK by O'Neill and O'Neill (2012), who warn that any move towards an "increasingly individualized, risk-sensitive regime" may lead to social blight. This underpins the argument for some form of cross-subsidization between low and high risk homeowners, as now formalized under Flood Re. In fact, the ABI argued for this at the beginning of the negotiations, stating that "no country in the world has a free market for flood insurance which provides affordable and accessible cover for high risk households without some form of government involvement and it makes no sense to rule out a subsidy before DEFRA have even done the analysis. To ensure potentially 200,000 high risk households have access to flood insurance in 2013, the government needs to...help develop a sustainable subsidy model which is paid for either by taxpayers, low risk households or both" (ABI, 2011). However, what remains less clear is how such a 'sustainable subsidy model' should look like, given that in the long-term, Flood Re's key objective is to provide a smooth transition to a free market that applies risk reflective pricing. For government and insurers this means that a combination of amending premium thresholds and reducing flood risk will be necessary to keep flood insurance affordable (Flood Re 2016b). However, the cost of flood insurance may have a negative effect on take-up rates of flood insurance by low-income household groups, particularly if the levy would have to rise. This will require a careful strategy of targeted subsidies and increasingly risk-based pricing. Flood Re's current pricing model of using council tax as a rating criteria appears less suitable for this:

. The pool's use of council tax bands (see Figure 3 above) as a means of setting premiums will likely continue to lead to a different kind of cross-subsidization because council tax bands are an indicator of wealth, not risk (Institute and Faculty of Actuaries, 2016). Households which are asset rich but income poor can expect to pay more for flood insurance due to the higher council tax (more valuable house equals higher council tax band) than those which are asset poor but have significantly higher disposable income but invest in different assets than their home. (Herrington \& Carmichael Solicitors, 2009).,

Indeed Davey (2015) highlights some regional disparities between the council band categories, noting that “...the level of Band A-H houses varies considerably between regions and is not perfectly correlated with levels of disposable income. It represents instead historic differences in property value" (Davey, 2015). 
Any distributional impacts arising for those outside the scope of Flood Re, or those who are not insured, remain unclear. SMEs and properties built after 2009 are not eligible for Flood $\mathrm{Re}$, and it has been argued that this places an unfair burden on SMEs and new home owners. However, while the 2009 exclusion rule is presented as a measure to avoid new development in high risk areas, it could be subject to political lobbying and be amended. This cut-off date may also raise serious questions of justice in the future; for example, what if building on flood plains becomes cheaper, and it is the poorest who bear the brunt of flooding? Should new developments in this context be excluded?

For SMEs, the British Insurance Brokers' Association has confirmed that it is working on developing a scheme to make flood insurance more affordable (Barton, 2016). The government has also announced that it is considering a Flood Re style mechanism for SMEs (Axling, 2016). However, Flood Re maintains the position that because of the differences in risk (for example, with regards to BI) a joint pool of homes and SMEs would be unworkable.

Importantly, even though the rate of insurance penetration in the $\mathrm{UK}$ is very high, there is need for additional disaster aid. Not all flooding costs are insurable. This is because many of these costs are not identifiable or financially measurable. On a personal level, these include the loss of items of sentimental value, and the loss caused by long-term damage to land. For example, there are concerns that land fertility in Somerset has been significantly reduced due to hectares of land being inundated for multiple months (Flood Block, 2015). Furthermore, insurance will not cover the costs of emergency procedures and repairs faced by local authorities. Instead, these costs become covered by initiatives such as the Bellwin Scheme, which reimburses local authorities for amounts spent on "taking...immediate action to safeguard life or property; or...prevent[ing] suffering or severe inconvenience in their area or among their inhabitants" (Sandford, 2015). As such, pre and post-event financing, despite the existence of Flood Re, will continue to be covered by a mixture of insurance, government investment and unilateral homeowner behaviour. This also applies to homeowners, who face the burden of paying for any home resilience measures, often supported through a government grant. As Flood Re does not subsidize resilience measures this might lead to an increased burden for homeowners (PenningRowsell and Priest, 2015).

The distribution of the costs of catastrophes under Flood Re is summarized in Table 4 below. 
Table 4. Distribution of the Costs of Catastrophes

\begin{tabular}{|l|l|}
\hline $\begin{array}{l}\text { How does this policy distribute the } \\
\text { costs of a disaster event? }\end{array}$ & $\begin{array}{l}-\quad \begin{array}{l}\text { Flood Re covers claims on ceded policies through insurer } \\
\text { premiums and } f 180 \mathrm{~m} \text { levy from insurers. } \\
\text { Insurance industry provides primary cover and cedes to } \\
\text { Flood Re or commercial reinsurance. }\end{array} \\
\begin{array}{l}\text { Government provides disaster relief to flood victims where } \\
\text { necessary (e.g. following Storm Desmond in 2015). } \\
\text { Government provides disaster relief to local authorities } \\
\text { where necessary (e.g. Bellwin scheme). }\end{array}\end{array}$ \\
\hline $\begin{array}{l}\text { Are there implicit or explicit cross- } \\
\text { subsidies among groups? }\end{array}$ & $\begin{array}{l}\text { Levy imposed on insurers replicates cross-subsidy that } \\
\text { existed prior to Flood Re (Diacon, 2013). }\end{array}$ \\
\hline $\begin{array}{l}\text { Is there some level of premium beyond } \\
\text { which consumers resist paying? }\end{array}$ & $\begin{array}{l}\text { No evidence - affordability will be reviewed as a criteria during } \\
\text { the 5-year reviews of Flood Re. }\end{array}$ \\
\hline $\begin{array}{l}\text { How are the most extreme events } \\
\text { financed? }\end{array}$ & $\begin{array}{l}\text { If Flood Re lacks funding, Flood Re can make a Levy II call on } \\
\text { insurers (Flood Re, 2016b). }\end{array}$ \\
\hline $\begin{array}{l}\text { What is the division between pre-event } \\
\text { and post-event financing? }\end{array}$ & $\begin{array}{l}\text { Flood Re liability limited to 1:200 year threshold. } \\
\text { Insurers pay premiums for ceded policies based on council } \\
\text { tax banding of properties. }\end{array}$ \\
\hline $\begin{array}{l}\text { If so, what is the criteria for their being } \\
\text { given assistance? }\end{array}$ & $\begin{array}{l}\text { Flood Re funded by } f 180 \mathrm{~m} \text { levy imposed on insurers. } \\
\text { Flood re pays out insurance claims to insurers, who then pay } \\
\text { out policyholders. }\end{array}$ \\
\hline $\begin{array}{l}\text { Are lower or middle income } \\
\text { households or small businesses given } \\
\text { premiums? }\end{array}$ & $\begin{array}{l}\text { Flood Re is designed to keep prices low and promote } \\
\text { affordability. No other assistance is provided as part of Flood Re. }\end{array}$ \\
\hline
\end{tabular}

\subsection{Technical Risk Cost Modelling and Risk Communication}

The insurance industry and Flood Re use a combination of in-house models, commercial models (such as RMS and JBA), and government data (such as Environment Agency and NAFRA ordinance surveys) to measure their exposure, diversify their portfolios and gain regulatory approval.

Flood risk modelling has made several advances in the UK, particularly in the commercial sector, where several models are available and continue to improve in resolution. For example, JBA Risk Management released a new high-resolution, multi-peril flood model for the UK in 2015 (JBA Risk Management, 2015). This model replaced JBA Risk Management's earlier Great Britain River Flood model. DEFRA and the Environment Agency have also tested 
the effectiveness of different 2D hydraulic modelling packages as part of the Flood and Coastal Erosion Risk Management Research and Development Programme (DEFRA and Environment Agency, 2013). The UK's flood maps are modelled using JBA Risk Management's software JFlow, demonstrating an alignment of industry modelling and publically available data (Clark, 2017). Figure 6 outlines the kinds of national flood maps currently existing in the UK. Despite these improvements some weaknesses remain, particularly with regards to mapping vulnerability based on flood area and monetary values, and factoring in effectiveness of flood risk management measures. Recent initiatives attempt to align public data and industry modelling, particularly with regards to incorporating flood defence information. Another key challenge is the lack of surface water flood risk information, where even very high resolution models show significant uncertainty. Furthermore, the impact of climate change on disaster event volatility is generally not included in these models due to the uncertain nature of climate change itself (Committee of Climate Change, 2016). Because of factors such as these, concerns remain with regards to the use of public data for insurance pricing.

\section{Figure 6. National Flood Maps}

\begin{tabular}{|c|c|}
\hline Map name & Shows \\
\hline Flood Map for planning (rivers and sea) & $\begin{array}{l}\text { The chance of flooding in any given year from } \\
\text { rivers and the sea, without defences, used } \\
\text { primarily for development and spatial planning } \\
\text { decisions }\end{array}$ \\
\hline $\begin{array}{l}\text { Risk of flooding from rivers and sea (also known } \\
\text { as the National Flood Risk Assessment } \\
\text { (NaFRA) }\end{array}$ & $\begin{array}{l}\text { The chance that any location will flood from } \\
\text { rivers and/or sea, taking account of flood } \\
\text { defences, in any given year }\end{array}$ \\
\hline Risk of flooding from surface water & $\begin{array}{l}\text { The chance that any location will flood from } \\
\text { surface water, in any given year }\end{array}$ \\
\hline Risk of flooding from reservoirs & $\begin{array}{l}\text { Areas that could be at risk of flooding in the } \\
\text { realistic worst case scenario of a major breach } \\
\text { of a reservoir }\end{array}$ \\
\hline
\end{tabular}

Source: HM Government, 2016.

Overall, any improvement in flood mapping technology would make it easier for insurers to individually price insurance policies, and also to decide whether or not to cede policies to Flood Re (Oliver, 2016). This reflects a movement away from the historical approach of pooling risk and cross-subsidizing between low and high risk policies (Oliver, 2016). The ABI sees riskreflective pricing as the optimum because, amongst other things, it encourages competitiveness and may promote risk reducing behaviour by policyholders, while also improving the insurability of households because there is greater information available to determine individual flooding 
risk, which allows greater differentiation between properties, to the benefit of those not at risk (ABI, 2008). However, at the same time, improvements in flood mapping can make premiums unaffordable for households in high risk areas (Oliver, 2016); indeed, protecting homeowners at high risk from risk-reflective pricing was the primary motivation for adopting Flood $\mathrm{Re}$ as a tool for transition. Similar concerns have triggered a review of flood insurance practices in Ireland, with a draft flood insurance bill calling for greater restraints by insurance companies when geocoding high risk areas (Surminski, 2017).

Interestingly, the discussion about pricing levels under Flood Re is somewhat flawed due to the lack of transparency about flood insurance pricing in general. As flood premiums are bundled with other home insurance costs, insurers usually do not disclose to their customers the premium load relating to their specific policies. It does not appear as a separate item on the standard home insurance policy and customers usually are only made aware of their risk status when a dedicated flood excess is charged. Any pricing information is therefore based on market estimates from insurers and brokers, and remain difficult to disaggregate or verify.

In addition to the lack of transparency about flood insurance pricing, there is also no clear risk communication between Flood Re and home owners, due to the pool's role as a reinsurer. It remains the decision of the relevant insurance company what information they share with customers and how flood risk is communicated, if at all.

Technical risk cost modelling and risk communication under Flood Re are summarized in Table 5 below.

Table 5. Technical Risk Cost Modelling and Risk Communication Under Flood Re

\begin{tabular}{|l|ll|}
\hline $\begin{array}{l}\text { How are technical risk costs modelled and } \\
\text { calculated by insurers and by Flood Re? }\end{array}$ & $\bullet \begin{array}{l}\text { Insurer: in-house models, commercial models (RMS, } \\
\text { JBA), government data (Environment Agency, NAFRA) } \\
\text { Flood Re uses JBA model. }\end{array}$ \\
\hline $\begin{array}{l}\text { To what extent is the "true" cost of the } \\
\text { risk visible to consumers? }\end{array}$ & $\bullet$ & $\begin{array}{l}\text { Not visible due to bundling of flood insurance with } \\
\text { household policies. Only visible if there is a flood excess. }\end{array}$ \\
\hline $\begin{array}{l}\text { Is cost of risks communicated effectively } \\
\text { by insurers/Flood Re? }\end{array}$ & $\bullet \begin{array}{l}\text { See above. } \\
\text { Separately, Flood Re does not communicated risks } \\
\text { directly to policyholders. }\end{array}$ \\
\hline $\begin{array}{l}\text { To what degree is risk-reflective rating and } \\
\text { insurance pricing occurring under Flood } \\
\text { Re? }\end{array}$ & $\begin{array}{l}\bullet \\
\text { - Flood Re does not impose rate setting on insurers. } \\
\text { Gre risk costs incorporated into property } \\
\text { design, prices, or development decisions? }\end{array}$ & $\bullet \begin{array}{l}\text { Exclusion of new properties from Flood Re discourages } \\
\text { development in high flood risk areas. }\end{array}$ \\
\hline
\end{tabular}




\begin{tabular}{|l|l|}
\hline & $\begin{array}{l}\text { Developments in high risk areas require a flood risk } \\
\text { assessment from developers. }\end{array}$ \\
\hline
\end{tabular}

\subsection{Incentives for Risk Reduction}

Although risk reduction was identified as one of the design principles for future flood insurance at the start of the negotiations for a renewed partnership (DEFRA, 2011), it is not a central aim of the new insurance pool (Surminski and Eldridge, 2015). Comparing the Statement of Principles approach and Flood Re (see Figure 7 below), Surminski and Eldridge (2015) conclude that no formal options for incentivizing risk reduction have been adopted in the new scheme.

Figure 7. Comparison of Statement of Principles with Flood Re

\begin{tabular}{|c|c|c|}
\hline Does the insurance system ... & Statement of Principles & Flood Re \\
\hline $\begin{array}{l}\ldots \text { increase risk awareness and } \\
\text { knowledge of risks through flood } \\
\text { risk information provision? }\end{array}$ & Yes & $\begin{array}{l}\text { No - but could change if Flood Re } \\
\text { loss data is shared. }\end{array}$ \\
\hline $\begin{array}{l}\text {... build capacity for risk reduction } \\
\text { through advice on risk reduction } \\
\text { measures? }\end{array}$ & $\begin{array}{l}\text { Limited - insurance industry has } \\
\text { provided advisory guidance for } \\
\text { home owners }\end{array}$ & No \\
\hline $\begin{array}{l}\text {... provide financial incentives for } \\
\text { policyholders toward mitigation } \\
\text { investment? }\end{array}$ & No & No \\
\hline $\begin{array}{l}\text {... promote resilient reinstatement } \\
\text { techniques after a flood loss? }\end{array}$ & No & No \\
\hline $\begin{array}{l}\text {... incentivize public flood risk } \\
\text { management policy? }\end{array}$ & Yes; is part of agreement & $\begin{array}{l}\text { Yes; see the Memorandum of } \\
\text { Understanding }\end{array}$ \\
\hline $\begin{array}{l}\text {...require compulsory risk } \\
\text { reduction? }\end{array}$ & $\begin{array}{l}\text { No for policyholders, yes for } \\
\text { government }\end{array}$ & No \\
\hline $\begin{array}{l}\text {... discourage development in } \\
\text { flood-risk areas? }\end{array}$ & Yes & Yes \\
\hline
\end{tabular}

Source: Author, based on Surminski and Eldridge (2015).

The one exception is the exclusion of post-2009 properties from Flood Re, which can be seen as an incentive for resiliency in developments in flood plains, or as a deterrent for new developments in high risk areas (Hoban, 2016). However, it is unclear whether this deterrent will have an effect in the long-term. Research suggests that the rate of residential development is 
increasing in floodplain areas and is higher than in other areas (Committee on Climate Change, 2015). 9\% of this development has been in high risk areas (Committee on Climate Change, 2015). This may be because Flood Re only became operational in 2016; the next few years will give a greater sense of the kind of impact Flood Re is capable of having on development.

Certain guidance and rules also exist, with new property developments in high risk areas requiring a flood risk assessment to support their planning application (Alexander et al., 2016). The ABI has also issued guidance to assist developers with building flood resilient properties through practical steps such as raising floor levels of properties (ABI, 2009b). However, it is unclear how successful these measures are and there is evidence that the costs of risks are becoming less of a concern, overridden by the growing concern about lack of housing, which has led to planning rules being less strictly applied. In particular, it appears that planning permissions have been granted for properties in floodplains even where the Environment Agency has rejected them on the basis of flood risk (ABI, 2009a). More recently, the government has adopted a policy of providing automatic planning permission on brownfield sites (Edgar, 2015). In 2017, it released a white paper containing proposals to address the UK's housing crisis, including but not limited to simplifying the planning process, and a planning framework for property developers that will provide quicker processing and determination of planning applications (Department for Communities and Local Government, 2017).

Beyond this, Flood Re does not have any direct levers to incentivize homeowners, insurers or government to reduce flood risk. There is (i) no formal scheme for building capacity for risk reduction, (ii) no requirement for compulsory risk reduction, (iii) no program for resilient reinstatement techniques after flooding, and (iv) limited commitment from government to do more for flood risk reduction (Surminski and Eldridge, 2015). However, Flood Re has committed to considering what role it can play to incentivize homeowners to adopt property level risk reduction measures within its first two years of operation (Flood Re, 2016b).

Despite the lack of levers, the risk reduction element remains particularly important for Flood Re because of its proposed transition to risk-reflective pricing. It is intended to provide a buffer to protect insurance customers from a steep rise in insurance costs, while gradually preparing them for a move towards risk-reflective pricing. If and how the transition to risk reflective pricing can be achieved without more risk reduction efforts remains very unclear (see also Section 5). This has led to criticism, with several commentators calling for Flood Re to provide better incentives for risk reduction measures (for example, see Alexander et al., 2016; and Surminski and Eldridge, 2015). In response Flood Re has now identified the need to build strong partnerships with a range of actors from the public, private and civil society sectors as a 
key strategy to ensure a successful transition phase (Flood Re, 2016b). Some options for this have been outlined in Figure 8:

\section{Figure 8. Examples of the Role that Flood Re Could Play in Helping to Reduce the Costs of Providing Flood Insurance}

\begin{tabular}{|c|c|c|c|}
\hline \multirow[t]{2}{*}{ Insurance cost driver } & \multicolumn{3}{|c|}{ Flood Re's potential role } \\
\hline & Direct lever & Indirect lever & $\begin{array}{l}\text { Role in supporting } \\
\text { action of others }\end{array}$ \\
\hline \multicolumn{4}{|l|}{ Risk of flooding } \\
\hline $\begin{array}{l}\text { Likelihood of } \\
\text { flood events }\end{array}$ & No & No & $\begin{array}{l}\text { Yes. For example, through } \\
\text { use of its data to guide } \\
\text { investment in flood } \\
\text { defences }\end{array}$ \\
\hline $\begin{array}{l}\text { Likelihood of } \\
\text { a given } \\
\text { household flooding }\end{array}$ & No & $\begin{array}{l}\text { Yes. For example, } \\
\text { through the } \\
\text { information it } \\
\text { provides on steps } \\
\text { householders might } \\
\text { take to protect } \\
\text { their property }\end{array}$ & $\begin{array}{l}\text { Yes. For example, through } \\
\text { building understanding of } \\
\text { the impacts of property } \\
\text { level resistance measures }\end{array}$ \\
\hline \multicolumn{4}{|l|}{ Costs of flood claims } \\
\hline $\begin{array}{l}\text { Severity of } \\
\text { flood event }\end{array}$ & No & No & $\begin{array}{l}\text { Yes. For example. } \\
\text { through use of its data } \\
\text { to guide investment in } \\
\text { flood defences }\end{array}$ \\
\hline $\begin{array}{l}\text { Cost of repair (including } \\
\text { re-housing) }\end{array}$ & No & $\begin{array}{l}\text { Yes. For example. } \\
\text { through the } \\
\text { information it } \\
\text { provides on steps } \\
\text { householders might } \\
\text { take to protect } \\
\text { their property }\end{array}$ & $\begin{array}{c}\text { Yes. For example, through } \\
\text { increasing understanding } \\
\text { of the impacts of } \\
\text { property level resistance } \\
\text { and resilience measures. } \\
\text { Also through the data it } \\
\text { holds on claims costs }\end{array}$ \\
\hline Administration & No & No & No \\
\hline \multicolumn{4}{|l|}{ Competition in the market } \\
\hline Number of firms & No & $\begin{array}{l}\text { Yes. The creation of } \\
\text { Flood Re should } \\
\text { encourage new } \\
\text { entrants into } \\
\text { the market }\end{array}$ & - \\
\hline Consumer engagement & No & $\begin{array}{l}\text { Yes. The creation } \\
\text { of Flood Re should } \\
\text { increase engagement } \\
\text { by giving households } \\
\text { more choice over their } \\
\text { household flood } \\
\text { insurance provider }\end{array}$ & - \\
\hline
\end{tabular}

Source: Flood Re, 2016b.

While the lack of resilience incentives available to Flood Re is a missed opportunity, there are still options to create greater support for flood risk reduction through the pool (Surminski and Eldridge, 2015); for example, one opportunity arises through Flood Re's own data sets. Over the course of its operation, the pool will have a map of high flood risk homes, a clearer picture of which of these homes are flooded, the cost of claims and how those costs are made up (Flood Re, 2016b). While it remains unclear how this information will be shared in the future, Flood Re is considering how it can be utilized to smooth the transition to risk-reflective pricing (Flood Re, 2016b). For example, the data could allow the government to calibrate 
measures for managing flood risk in different areas by providing the information necessary for a more thorough analysis of the effectiveness of different risk reduction measures (Surminski, 2017). It will also provide the information government needs to decide where to build new properties, and how to build them. More generally, sharing data may also help to shift the conversation between government and the insurance industry to a more long-term focus by helping to identify common concerns.

In addition, there are opportunities for Flood Re to collaborate with insurers to support risk reduction, such as in the context of resilient repairs after a flood, through information sharing and awareness raising, or combined government lobbying for flood risk management. Flood Re could also help to address key underlying barriers for risk reduction: Insurers do not necessarily value all kinds of risk reducing behaviour. For example, engineered defences are perceived as the "gold standard" for reducing vulnerability, whilst non-engineered measures such as warning systems are perceived as ineffective (DEFRA, 2016a). Meanwhile a survey of 400 homeowners in the UK by Lamond et al. (2009) shows that Insurers have also been ineffective in encouraging their policyholders to adopt flood mitigation measures. As Ball et al. (2013) state, the adoption of property level measures are difficult to assess so insurers do not necessarily see them as a basis for lowering policy costs. These challenges make it unclear how Flood Re can engage insurers, who do not necessarily see themselves as having a role to play in incentivising risk reduction. However, a good starting point would be an acknowledgement that risk reduction is crucial to the future availability of flood insurance (Prudential Regulation Authority, 2015), and that common ground therefore exists between government and industry in reducing risk. Data sharing may help to establish this rapport by promoting greater collaboration (Surminski, 2017).

Table 6 below summarizes Flood Re's role in incentivizing risk reduction. 
Table 6. Incentives for Risk Reduction

\begin{tabular}{|c|c|}
\hline $\begin{array}{l}\text { Does this program have explicit or } \\
\text { implicit incentives for reducing risk? }\end{array}$ & $\begin{array}{l}\text { - No formal incentives other than the post-2009 building } \\
\text { exclusion. } \\
\text { The first Flood Re transition plan commits Flood Re to } \\
\text { consider resilience initiatives within first two years of } \\
\text { operation. } \\
\text { - Some insurers encourage customers to apply for } \\
\text { government's resilience grant of } £ 5000 \text {. }\end{array}$ \\
\hline $\begin{array}{l}\text { Do we have evidence on the } \\
\text { magnitude of these incentives? }\end{array}$ & - $\quad$ No evidence available. \\
\hline $\begin{array}{l}\text { What are the relevant roles of the } \\
\text { public and private sectors in risk } \\
\text { reduction? }\end{array}$ & $\begin{array}{l}\text { - Government provides disaster aid for improving resilience } \\
\text { (HM Government, 2016). } \\
\text { - Some (but not all) insurers encourage resilience measures } \\
\text { (Surminski, 2014; and Lamond et al., 2009). }\end{array}$ \\
\hline $\begin{array}{l}\text { Is there any financing in the form of } \\
\text { loans and grants for hazard mitigation } \\
\text { as part of the program? }\end{array}$ & $\begin{array}{l}\text { No, but: } \\
\text { - } \quad \text { Disaster relief provided separately (HM Government, 2016). } \\
\text { - } \quad £ 700 \mathrm{~m} \text { investment in resilience measures (DEFRA, 2016a). } \\
\text { - } \quad £ 5000 \text { resilience grants for homeowners from government. }\end{array}$ \\
\hline $\begin{array}{l}\text { What has been the government's role } \\
\text { in risk protection/reduction and how } \\
\text { can this role be shown to have } \\
\text { influenced the pricing and take up } \\
\text { rates for disaster insurance? }\end{array}$ & $\begin{array}{l}\text { - } \quad \text { Per above. } \\
\text { - } \quad \text { Ine pricing impact is difficult to determine. } \\
\text { but don't value non-structural measures. } \\
\text { - Environment Agency's Long Term Investment strategy. } \\
\text { - No evidence of specific pricing impact. }\end{array}$ \\
\hline $\begin{array}{l}\text { Is their assistance in financing risk } \\
\text { reduction for lower or middle income } \\
\text { households? }\end{array}$ & $\begin{array}{l}\text { - } \quad \text { Not as part of Flood Re. } \\
\text { - } \quad \text { See other assistance above and in notes. }\end{array}$ \\
\hline $\begin{array}{l}\text { What roles do zoning, building codes, } \\
\text { and land use play in connection with } \\
\text { insurance? }\end{array}$ & $\begin{array}{l}\text { Business properties not covered by Flood Re (House of } \\
\text { Commons, 2016). } \\
\text { - } \quad \text { New housing developments not covered. } \\
\text { - } \text { Mixed-use properties generally out of scope (Flood Re, } \\
\text { 2016c). } \\
\text { - ABI guide for property developers in } 2009 \text { (ABI, 2009b). }\end{array}$ \\
\hline
\end{tabular}

In conclusion, the lack of risk reduction incentives creates significant challenges for Flood Re in the face of changing risks. This is discussed in Section 5. 


\section{Evaluating Flood Re: Fit for Purpose and Fit for the Future?}

Although Flood Re has only been operational for a short period of time, the above assessment provides some valuable pointers for a first evaluation. The data collected is underpinned by recent quantitative and qualitative analysis, conducted prior to Flood $\mathrm{Re}$ becoming operational, including the UK government's economic impact assessment for Flood Re (DEFRA, 2014), an actuarial evaluation of government's insurance modelling (Diacon 2013), an agent-based model assessing Flood Re's operation in the face of future climate change (Jenkins et al., 2017), and a qualitative analysis of the design process, aims and objectives of Flood Re with a special consideration of flood risk reduction (Surminski and Eldridge, 2015; and Surminski and Hudson, 2017). While these calculations and assessments offer only estimates and are based on underlying assumptions rather than evidence from the market, they still provide useful insights into the mechanics and performance of Flood Re under certain conditions.

The evaluation looks at two dimensions: is Flood Re "fit for purpose" in terms of achieving its statutory aims and objectives; and does the pool offer a forward looking solution to address the challenges that led to its creation - in other words, is it "fit for the future"?

\subsection{Fit for Purpose?}

An insurance mechanism created by public policy is subject to different expectations, ambitions and assumptions amongst government, industry and other stakeholders. Whether or not these are met once the mechanism is in operation depends on many factors, including design, behaviour and risk characteristics. A useful starting point for any evaluation is therefore the underlying aims and objectives for Flood Re. At the start of the negotiations, a set of principles were published by DEFRA, outlining the vision for flood insurance (see Figure 9): 
Figure 9. Principles for Flood Re Negotiations

Principles
1. Insurance cover for flooding should be widely available.
2. Flood insurance premiums and excesses should reflect the risk of flood damage to
the property insured, taking into account any resistance or resilience measures.
3. The provision of flood insurance should be equitable.
4. The model should not distort competition between insurance firms.
5. Any new model should be practical and deliverable.
6. Any new model should encourage the take up of flood insurance, especially by low-
income households.
7. Where economically viable, affordable and technically possible, investment in flood
risk management activity, including resilience and other measures to reduce flood
risk, should be encouraged. This includes, but is not limited to, direct Govemment
investment.
8. Any new model should be sustainable in the long run, affordable to the public purse
and offer value for money to the taxpayer.

Source: DEFRA, 2011.

While offering a very comprehensive list of features for sustainable flood insurance, it became obvious during the negotiations that stakeholders saw clear trade-offs between those principles, particularly between affordability and risk-reflective pricing (Surminski and Eldridge, 2015). In subsequent negotiations, the remit of the new flood insurance intervention was limited to principles 1, 3 and 8, stating at its core the aim to "ensure the availability and affordability of flood insurance, without placing unsustainable costs on wider policyholders and the taxpayer" (DEFRA, 2013).

For Flood Re this implies that it has to satisfy multiple objectives. It seeks to maintain market autonomy, keeping the role of government as minimal as possible, and it is conceived as a transitional tool, in order to pave the way towards risk-reflective pricing in a private market.

Evaluating the overall cost effectiveness of the Flood Re policy intervention is complicated as it requires more than a basic assessment of the extent to which, for example, a subsidy to an insurance provider translates into a reduction in premiums. To fully capture the cost effectiveness of insurance interventions, a wider view of the relevant insurance market has to be taken. Overall, it will be the behaviour of market participants that will determine how Flood Re will be used, what risks will be ceded, the costs of reinsurance for Flood Re itself, and if Flood Re will have an impact on primary cover provision. There is commitment and the fact that Flood Re has been proposed by the industry indicates that there is willingness from companies to use it as a mechanism to support low flood insurance premiums. 
As such, first indicators show that the private market has adopted Flood Re. Since inception, Flood Re is estimated to have underwritten 53,000 policies (based on personal communication with Flood Re in October 2016), while the stated annual aim is to reach 350,000 policies. As it is outside Flood Re's control whether or not insurers decide to cede their policies, it is difficult to interpret these initial figures.

Flood Re's ability to pay after a flood event has not been tested, but it had to gain regulatory approval under the same conditions as any private market provider, so an acceptable level of solvency can be expected. However, it is unclear what would happen should the Flood Re pool be exceeded. As discussed above, a levy II call can be made, but if a flooding event exceeds the 1:200 threshold, the government will work with the industry to explore available options. Importantly, there is no financial commitment from the government to provide public funds should the Flood Re pool be depleted. This can be seen as a significant achievement for the government, who had to resist lobbying from industry throughout the Flood Re negotiations to provide financial guarantees for risks beyond the Flood Re cap and in case that Flood Re's funds should not be sufficient to pay for claims. However, for some observers there is still a clear anticipation that government would pay for events beyond the 1/200 PML level (Hornstein, 2015).

Early figures also suggest that the price of insurance has remained stable and there have been no reports of homeowners struggling to access flood insurance. This indicates that Flood Re is delivering on its key aim of ensuring availability and affordability, but a full evaluation will only be possible once Flood Re establishes what risks have been ceded and once it is tested by a significant flooding event. Market studies to monitor any changes in availability and affordability of cover will be required throughout its operation.

Reducing the insurance premium for those at high risk can be considered a necessary but not sufficient condition for cost effectiveness. Changes in take-up rates of insurance are currently not visible, but would also need to be monitored. A better picture of cost effectiveness would emerge with an understanding of any possible deadweight loss, which captures the degree to which the intervention "wastes" money by providing transfers without changing behaviour. A full appraisal of Flood Re would also need to consider the primary and secondary benefits derived from the pool, as well as any perverse or unintended effects.

In fact, the cost effectiveness of Flood Re has been questioned by government, openly declaring that the proposed scheme does not meet the minimum government standard for costbenefits (DEFRA, 2013). Consequently, the Secretary of State had to sign an exemption 
statement, justifying the policy intervention despite not meeting cost-benefit targets. A key argument for the justification came through the wider benefits of Flood Re, referencing "wider socio-economic and equity reasons for pursuing the Flood Re scheme which are not fully reflected in the strict value for money calculations made in this Impact Assessment - for example it brings more certainty to future evolution of insurance prices with beneficial effects not only on policy holders but also in other markets such as the property market and mortgage lending. Flood Re also ensures industry support in managing a smooth transition during the interim period between the Statement of Principles ending and the new policy coming in" (DEFRA, 2014). This has been criticized (for example, see Hjalmarsson, 2015), but has not interfered with the parliamentary approval process, indicating the high political will to get Flood Re into operation. Another key justification for Flood Re's political approval despite its costliness was the argument that Flood Re does not create new forms of subsidization, but merely formalizes the already existing degree of cross-subsidization. This was one of the main reasons why Flood Re gained the EU's State-Aid-Exemption approval, alongside its transitional nature (Surminski et al., 2015). In its review, the European Commission recognized the goal of ensuring affordable insurance against flood risk as a legitimate scope of public policy and adopted the decision not to raise objection. The European Commission acknowledged that the pool was designed so as to minimize the (competitive) advantage granted to the insurers (Mysiak and Pérez-Blanco, 2016).

However, a recent report from the Finance Department in Ireland concluded that Flood Re had much higher set up costs than originally anticipated (Interdepartmental Flood Policy Coordination Group ("IFPCG"), 2016), which led to the conclusion that the pool would be too costly a model for Ireland to follow. In particular, the Finance Department noted that the costs of such a scheme would have to be spread over a much smaller number of households, raising questions over its viability (IFPCG, 2016).

\subsection{Fit for the Future?}

Flood Re's other key objective is to provide a smooth transition to risk-reflective pricing. The first Flood Re transition plan, published in early 2016, seeks to provide a framework through which future transition plans for removing the subsidy provided under Flood Re can be analysed and implemented. In particular, it notes that a combination of amending premium thresholds and encouraging disaster risk reduction strategies will be necessary to keep flood insurance affordable as it transitions to risk-reflective pricing. This will need to be carefully balanced. If such cross-subsidization remains, there may be little incentive for policyholders in high floodrisk areas to make their properties more resilient, making premium levels unsustainable 
following transition to a risk-reflective market. To reiterate, creating this incentive is seen as one of the key benefits of risk-reflective pricing (see ABI, 2008; and Oxera, 2015).

Figure 10 demonstrates how premium thresholds would have to change over time in order for Flood Re to transition to risk-reflective pricing. " $D$ " and "G" refer to the council tax band of properties. "Outcome B" refers to "a market where household flood insurance is widely available at a price that is regarded as affordable".

\section{Figure 10. Indicative Potential Changes to Premium Thresholds}

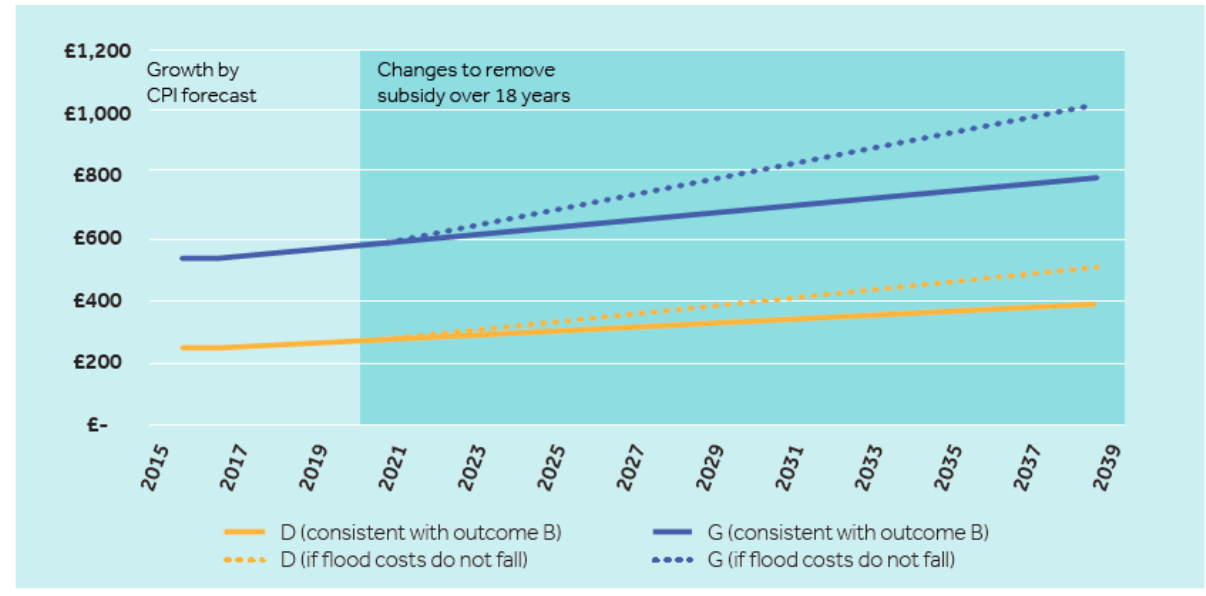

Source: Flood Re, 2016b.

According to the first Flood Re transition plan, Flood Re aims to phase out the annual insurer levy of $£ 180 \mathrm{~m}$ by gradual price reduction, while attempting to maintain premium threshold levels, through the following combination of factors: reduction in risk of flooding, reduction in cost of flooding, and increased competition in the insurance market (Flood Re, 2016b). However, it remains unclear whether or not the risk environment would allow such a transition. This raises the question whether Flood Re is fit for the future.

Rising losses and increased volatility can affect the fine balance between affordability and profitability for insurers. In extreme cases this could lead to insurers withdrawing from certain markets and regions, as highlighted by the Prudential Regulation Authority (Prudential Regulation Authority, 2015). While the recent flood loss trends in the UK are largely due to socio-economic factors, such as more development in exposed areas, climate change is expected to exacerbate these impacts (IPCC, 2013). One important aspect therefore is if and how flood insurance provision can be integrated into overall risk management and climate change adaptation efforts, and how insurers can collaborate with other stakeholders (particularly the government) to achieve greater resilience and ensure future insurability. 
The lack of risk reduction incentives can therefore be seen as a major drawback for Flood Re. The Committee on Climate Change has found that, in its current design, Flood Re is likely to be counter-productive to the long-term management of flood risk as it does not provide enough incentives for high-risk households to put measures in place to avoid or reduce flood damage (Committee on Climate Change, 2015). This raises the question of whether, in its current format, Flood Re will achieve its aim of moving towards risk-reflective pricing while maintaining insurance affordability.

Indeed, a recent study by Jenkins et al. (2017) finds that Flood Re is likely to lead to an increasing gap between subsidized premiums and technical risk price, as summarized in Figure 11. These findings were highlighted by the Bank of England in its first report on the impact of climate change on the insurance industry, calling for more efforts to address underlying risk drivers (Prudential Regulation Authority, 2015).

Figure 11. Pricing implications of rising risks levels

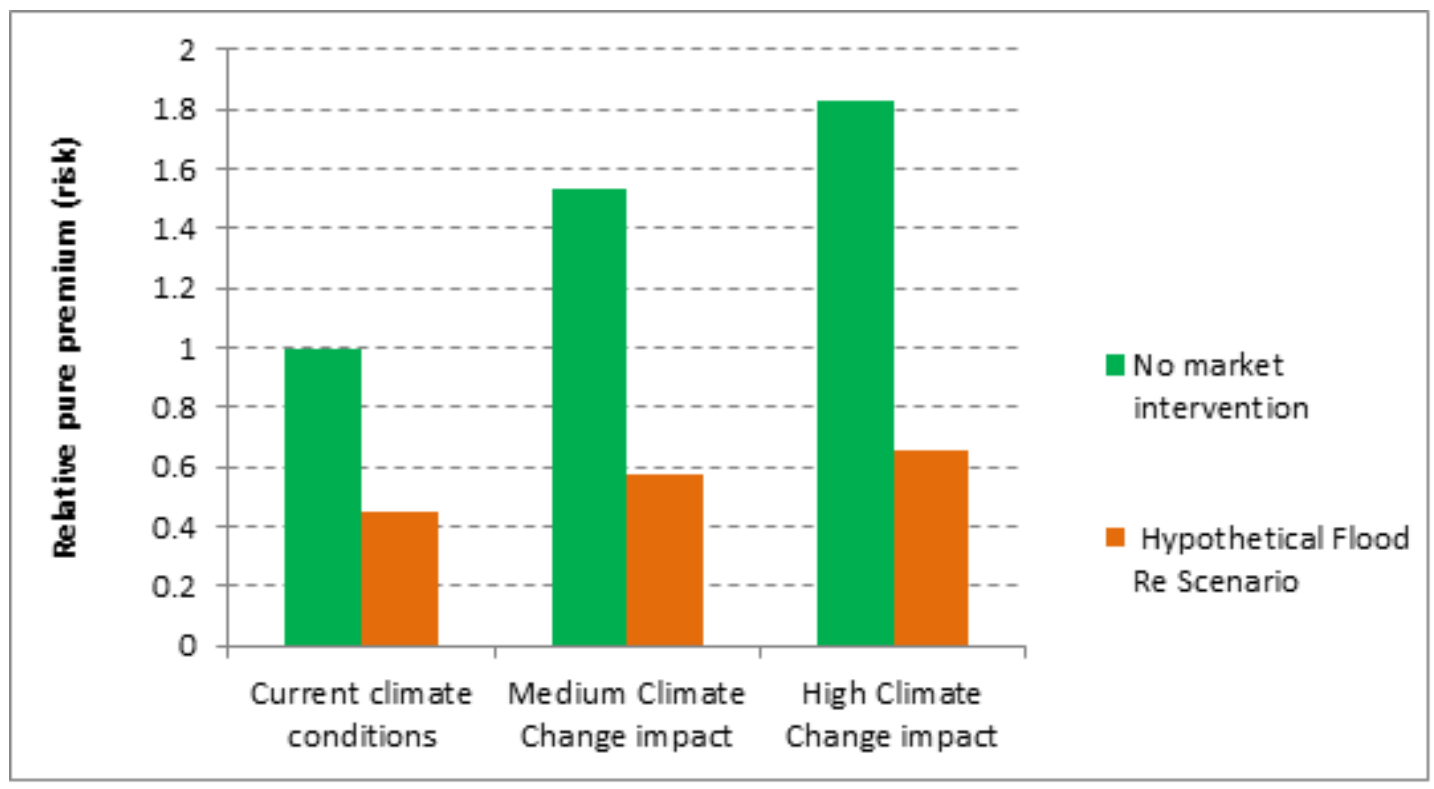

Source: adapted from Jenkins et al., 2017 and Prudential Regulation Authority, 2015.

The underlying agent-based model simulation of Flood Re shows that the pool is beneficial in its function to provide affordable insurance, even under climate change; in particular, the study finds that Flood Re would achieve its aim of securing affordable flood insurance premiums. However, the analysis also highlights that Flood Re would be placed under increased financial strain if challenged with increasing risk as highlighted by future climate change projections. If the intended transition to risk-reflective pricing is to take place, then a determined and coordinated strategy would be needed to manage flood risk, which utilizes 
insurance incentives, limits new development, and supports resilience measures (Jenkins et al., 2017).

The agent-based model also provides a platform to investigate the transitional mechanisms recently proposed as part of the Flood Re scheme (Flood Re, 2016b), as well as how changes to regulatory measures and the roles and behaviour of different stakeholders could be enhanced to support flood risk reduction under future climate change (Jenkins et al., 2017). A key issue is how the scheme will cope with the increasing gap between subsidized and riskreflective premiums given urbanization and climate change, and what impact an increase in demand for Flood Re could have. While the simulations indicate that Flood Re could ensure the affordability of insurance to homeowners, even under future climate change, this is modelled here without constraint on the number of properties which can be placed into Flood Re. However, an extension of Flood Re to include more properties could have significant consequences for Flood Re's funds and reinsurance cover, with affordable cover becoming harder to sustain under the future scenarios.

In conclusion, there are several pressure points that could threaten the proposed transition to risk-reflective pricing. If flood risk continues to rise, this would be likely to increase take-up under Flood Re, while the gap between technical risk price and the Flood Re price would continue to widen. This would become a major challenge for government, which might have to intervene to plug this widening gap by providing funds or back-up cover for Flood Re. Political will, risk behaviour and, most importantly, the success of public flood risk management policies will determine the future of Flood Re. For many observers Flood Re is a stop-gap, or "a breathing space for government to implement more resilient flood defences" (Institute and Faculty of Actuaries, 2016).

\subsection{Suggestions}

In light of these limitations, a number of suggestions can be made to improve Flood Re's performance. Perhaps most importantly, Flood Re will not achieve risk reduction on its own. Even if it does encourage some policyholders to reduce their own risk, it may not be the case that those investments are effective or have a positive effect on insurance premiums. Instead, a broad suite of stakeholders ranging from banks, developers and architects to local government authorities need to be suitably engaged if the goal of reducing flood risk is to be achieved. This is discussed by Crick et al. (2016), who demonstrate through the application of an agent-based model that engaging other stakeholders, particularly developers and local government authorities, can have a positive impact on risk reduction. For example, their analysis shows that 
requiring developers to build new properties with sustainable drainage systems can significantly reduce flood risk; however, imposing additional financial obligations on developers (e.g. requiring developers to pay a share of flood insurance) may not have a significant impact. Importantly, this also suggests that flood insurance itself may have a limited role to play in engaging other stakeholders. Similarly, Crick et al. (2016) demonstrate that simply requiring local government authorities to approve new developments has little impact on flood risk. However, a combined approach of, for example, local governments setting a more stringent development approval ratio together with setting lower acceptable flood risk levels can have a positive impact on reducing flood risk.

More generally, Jenkins et al. (2017) demonstrate the significant impact that sustainable drainage systems and other property level protection measures can have on reducing flood risk, with their research suggesting reductions of up to $23 \%$ are possible. This supports a measure such as requiring developers to include sustainable drainage systems in new developments. However, Jenkins et al. (2017) also demonstrate that investment in such measures may not be sufficient to prevent flood risk increasing over time, particularly in the context of climate change. As such, the gap between subsidized and risk-reflective premiums under Flood Re is likely to continue increasing, and this raises serious questions of how policyholders will be able to afford premiums after Flood Re transitions to risk-reflective pricing. This also appears to limit the role that banks and other lending institutions, which have a clear interest in promoting risk reduction in order to safeguard their mortgage agreements, can play in flood risk management. However, there remains a lack of analysis around this issue, and further statistical studies taking into account action by a broader range of stakeholders may suggest otherwise. The author recommends further studies into such dynamics. Innovation in property level protection measures may also make a significant contribution in the future.

\section{Concluding Observations}

Flood insurance is technically challenging and often highly politically charged, with questions of fairness, justice, and effectiveness appearing at the interface between public and private sector activities. Therefore, any effort to reform an existing scheme or introduce a new insurance solution needs to reflect on the broader context: what are the aims and objectives of different stakeholders? Where is existing capacity to underwrite, inform, incentivize, and take action to reduce risks? And how can insurance provide a mechanism that allows transparency about risk levels and risk trends, ensures fair and equitable access to those who need it while not creating unnecessary burdens for those who do not? Addressing these points is difficult in any 
context, but when changing risk levels and conflicting views on responsibilities and ownership are added to the mix this becomes one of the infamous "wicked problems" of planning and decision-making (Rittel and Webber, 1973).

This explains why there is such a patchwork of flood insurance approaches in operation across the world, and why a large number of countries still have no such insurance at all.

In broad terms, the approaches follow either a solidarity-based concept, such as in France, where mandated through the government, all policyholders contribute and thus support those at high risk. The alternative is a fully risk-reflective approach, using risk-reflective pricing as a way to steer individuals and society towards a more resilient future. While this is widely seen as the rational way forward, in many cases, it is politically impossible without significant subsidization of those facing costly insurance premium. Flood Re can be seen as an effort to bridge both worlds - a solidarity based first phase, which would then gradually shift towards a risk-reflective system in the longer run. Still, there remain questions about eligibility, which appear subject to political lobbying rather than based on sound technical assessment. Hence, Flood Re's scope of cover might be adjusted, with SMEs and new-build properties potentially becoming eligible for cover. For Flood Re, the expansion of scope and rising take-up rates by insurers would require a revision of the underlying funding model and might lead to a reassessment of the required size of the pool funds.

Overall the success of Flood Re will heavily depend on risk trends, loss events, and market behaviour. A series of floods, together with an improved understanding of growing future risks, vulnerabilities and exposure levels would place strain on any insurance system, public or private. The only truly sustainable response would be a significant increase in efforts to address the underlying risks by the government. Anything to reduce likelihood of loss would help to secure affordability and availability of insurance. This would also support those who are not benefitting from insurance by resilient communities, businesses and individuals, which in turn would help address the broader costs of floods, including those intangible aspects such as emotional stress, health issues or economic competitiveness for communities and regions.

In times of rising risk, this is the main selling point for insurance: if correctly designed and implemented, it can be very influential in driving societal resilience, while also delivering economic benefits. However, as Flood Re shows, this is still lagging in practice. And indeed, there are concerns that flood insurance can de-incentivize resilience, creating a false sense of security. This is the area where Flood Re could play a significant role by sending the right 
signals that would help to prepare homeowners for a risk-reflective approach to insurance. But until today this remains a missed opportunity.

The debate about flood insurance in the UK thus illustrates a fundamental challenge: the concern about affordability is usually seen in a short-term context, often driven by election cycles and the one-year nature of insurance contracts, while there is no strategy for the longer-term. Kunreuther and Michel-Kerjan (2009) support this, noting that short-term election considerations mean politicians may choose to focus on areas with more political capital (e.g. providing disaster assistance with immediately visible benefits rather than focusing on risk reduction, where the benefits tend to be derived in the long-term). As such, less focus may be placed on risk reduction due to its non-immediate benefits. While it is laudable that the government appears committed to risk-reflective pricing, whether or not this will be achieved through Flood Re remains highly questionable. The pool has a 23 year life span and is built on the assumption that over this time government, homeowners and other stakeholders will do their bit to reduce flood risk, thus leading to a situation where no further public intervention in the market would be required. As the above evaluation shows, this appears to be wishful thinking rather than a sound strategy. Flood Re, government and industry now need to explore how to support this transition. This would require a clear commitment to risk reduction and flood resilience, recognizing that this is the only viable way to ensure future insurability of these risks [Surminski and Thieken 2017; see also Ermoliev et al., 2000 for an earlier investigation of this].

This paper shows that insurance's broader role of supporting flood resilience and flood risk reduction is far from exhausted and that there is the possibility to enhance this further through better collaboration between industry and government.

The challenges faced by Flood Re therefore raise a number of important policy implications:

Firstly, in order to harness Flood Re to increase overall resilience, greater involvement is needed from other agents whose behaviour determines the flood resilience of homes. Banks, property developers, planning officials, architects, local government and the built environment industry are just a few of those stakeholders who are indirectly benefitting from insurance without paying for it, and whose actions determine the resilience of buildings and systems. There is the possibility for insurance to incentivize and engage those stakeholders (Crick et al., 2016), but at the moment how it can do so is still largely unexplored.

Secondly, the distributional effects of Flood Re merit further attention. This applies to the treatment of SMEs, who may need a separate flood insurance scheme going forward (Axling, 
2016), as well as to inequities that arise through the use of council tax banding as a rating mechanism.

Thirdly, the data collected by Flood Re should be harnessed with a view to addressing the above two problems. In relation to the first, it can promote collaboration between stakeholders and raise the profile of flooding as a long-term problem for the insurance industry which requires long-term thinking. Loss data may also help to engage other stakeholders wishing to understand how to manage their own vulnerabilities (e.g. mortgage providers). In relation to the second, Flood Re's data collection will provide a wealth of information that will allow the government to target risk reduction measures to those areas most in need (and therefore may reduce the negative effects of Flood Re's transition to risk-reflective pricing for high-risk households regardless of council tax banding).

Ultimately, it is very clear that insurance is not a silver bullet, and it needs to be supported and integrated into a solid flood risk management approach. This is important for those countries that have insurance, but even more so for newly emerging markets or developing countries. Insurance against floods or other climate risks should be considered with healthy scepticism unless it can be developed with risk reduction and stakeholder influence in mind. Therefore it is important that Government, insurers and homeowners understand that the success of Flood Re will depend on how well flood risk is managed. The pool should become a lever for more investment in flood defences, more efforts to increase property resilience and improved land-use. Flood Re's Memorandum of Understanding captures some of this spirit, but remains more vague than its predecessor, the Statement of Principles. The commitments made under the Memorandum of Understanding include spending $£ 2.3$ billion on flood defences to 2021 (Flood $\mathrm{Re}, 2016 \mathrm{~b}$ ) but there is scepticism that the government will achieve its protection targets (Environmental Audit Committee, 2016).

Overall, it is still very early days for Flood Re, and much of the underpinning analysis in this paper is driven by assumptions, expectations and scenarios, rather than hard evidence from the market. It is therefore very important for Parliament and the insurance regulator to monitor all the variables outlined above and see how Flood Re and the wider market perform and fulfil the statutory duties under the Flood Re legislation. Importantly, this should not simply focus on pure underwriting practices, but it should also consider how wider risk trends and flood risk behaviour develop. Therefore Flood Re's activities should also be closely monitored by those tasked with assessing the UK's response to climate risks, such as the Committee on Climate Change. And importantly, as this paper shows, this monitoring should look at both Flood Re's performance today as well as its ability to play a role in supporting societies' flood resilience. 



\section{References}

Alexander, M., S. Priest, A.P. Micou, S. Tapsell, C. Green, D. Parker and S. Homewood. 2016. "Analysing and evaluating flood risk governance in England-Enhancing societal resilience through comprehensive and aligned flood risk governance arrangements". STAR-FLOOD Consortium. Flood Hazard Research Centre, Middlesex University. ISBN 978-94-91933-07-3.

Arrow, K. 1968. “Optimal Capital Policy with Irreversible Investment”. In Wolfe, J. N. (ed.). 1968. "Value, Capital and Growth". Aldine Publishing Co., Chicago.

Association of British Insurers (ABI). 2005. "ABI Statement of Principles on the provision of flood insurance". Association of British Insurers, London.

Association of British Insurers (ABI). 2007. "Access for all: Extending the reach of insurance protection”. Association of British Insurers, London.

Association of British Insurers (ABI). 2008. "Insurance in the UK: The Benefits of Pricing Risk". Association of British Insurers, London.

Association of British Insurers (ABI). 2009a. "Flood insurance at risk if Environment Agency concerns are ignored says ABI". Association of British Insurers, London.

Association of British Insurers (ABI). 2009b. "Climate Adaptation - Guidance on Insurance Issues for New Developments". Association of British Insurers, London.

Association of British Insurers (ABI). 2010. "Spending Review ABI comments on flood investment plans". Association of British Insurers, London.

Association of British Insurers (ABI). 2011. "ABI responds to Government update on the future of flood insurance”. Association of British Insurers, London.

Association of British Insurers (ABI). 2013. "ABI and Government agree Memorandum of Understanding on scheme to safeguard UK flood insurance". Association of British Insurers, London.

Association of British Insurers (ABI). 2015. "UK Insurance \& Long Term Savings - Key Facts 2015”. Association of British Insurers, London.

Association of British Insurers (ABI). 2016. "Home insurance premiums remain stable despite winter floods". Association of British Insurers, London.

Aviva PLC. 2016a. "Half Year 2016 Earnings Presentation - Final”. Aviva PLC. 
Aviva PLC. 2016b. "Aviva ready to offer homeowners Flood Re enabled prices”. Aviva PLC.

Axling, I. 2016. “Government looking at a Flood Re style for SMEs, says Cameron”. Insurance Age. Available at: http://www.insuranceage.co.uk/insuranceage/news/2456284/government-looking-at-flood-re-for-smes-says-cameron [accessed 3 October 2016].

Ball, T., A. Werritty and A. Geddes. 2013. "Insurance and sustainability in flood-risk management: the UK in a transitional state". Volume 45 Issue 3 Area.

Barton, S. 2016. "Biba seeks to develop SME flooding solution". Insurance Age. Available at: http://www.insuranceage.co.uk/insurance-age/news/2441992/biba-seeks-to-develop-smeflooding-solution [accessed 4 October 2016].

BMI Research. 2016. “United Kingdom Insurance Report Q4 2016”. Business Monitor International Ltd.

Brainard, L. 2008. "What is the role of insurance in economic development?" Zurich Government and Industry Thought Leadership Series (No. 2). Available at: https://www.draudimas.com/allpics/What_is_the_role_of_economic_developement.pdf [accessed 13 December 2016].

Brignall, M. 9 May 2012. "Council tax - are we all in it together?" The Guardian. Available at: https://www.theguardian.com/money/2012/mar/09/council-tax-in-it-together-anomalies [accessed 9 September 2017].

Cabinet Office. 2015. “National Risk Register of Civil Emergencies: 2015 edition”. Cabinet Office. Available at: https://www.gov.uk/government/uploads/system/uploads/attachment_data/file/419549/20 150331_2015-NRR-WA_Final.pdf [accessed 13 December 2016].

Clark, F. 2017. "Mapping Flood Risk in the UK". LiDAR News.

Committee on Climate Change. 2015. "Progress in preparing for climate change: 2015 Report to Parliament". Committee on Climate Change. Available at: https://www.theccc.org.uk/wpcontent/uploads/2015/06/6.736_CCC_ASC_Adaptation-ProgressReport_2015_FINAL_WEB_250615_RFS.pdf [accessed 10 October 2016]

Committee on Climate Change. 2016. "UK Climate Change Risk Assessment 2017 - Synthesis report: priorities for the next five years". Committee on Climate Change. Available at: 
https://www.theccc.org.uk/wp-content/uploads/2016/07/UK-CCRA-2017-SynthesisReport-Committee-on-Climate-Change.pdf [accessed 8 October 2016].

Crichton, D. 2008. "Towards a comparison of public and private insurance responses to flooding risks”. Volume 24 Issue 4 International Journal of Water Resources Development.

Crick, F., K. Jenkins and S. Surminski. 2016. "Strengthening insurance partnerships in the face of climate change - insights from an agent-based model of flood insurance in the UK". Grantham Research Institute on Climate Change and the Environment Working Paper No. 241, Centre for Climate Change Economics and Policy Working Paper No. 271. Available at: http://www.lse.ac.uk/GranthamInstitute/wpcontent/uploads/2016/06/Working-Paper-241-Crick-et-al.pdf [15 December 2016].

Davey, J. 2015. "Flood Re: Risk Classification and 'Distortion of the Market". In Hjalmarsson, J (ed.). 2015. "Future directions of consumer flood insurance in the UK". University of Southampton. Available at: https://www.southampton.ac.uk/assets/imported/transforms/contentblock/UsefulDownloads_Download/5833464F560E457BBB32BE07A53B9419/58175_R eport_v4_WEB.pdf [accessed 13 December 2016].

Department for Communities and Local Government. 2017. "Fixing our broken housing market". Crown. Available at: https://www.gov.uk/government/uploads/system/uploads/attachment_data/file/590464/Fi xing_our_broken_housing_market__print_ready_version.pdf [accessed 22 June 2017].

Department for Environment, Food and Rural Affairs (DEFRA). 2011. "Flood risk and insurance: A roadmap to 2013 and beyond". Final report of the flood insurance working groups. DEFRA, London.

Department for Environment, Food and Rural Affairs (DEFRA). 2013. "Securing the future availability and affordability of home insurance in areas of flood risk". DEFRA, London.

Department for Environment, Food and Rural Affairs (DEFRA). 2014. "Managing the future financial risk of flooding: Impact Assessment". DEFRA, London.

Department for Environment, Food and Rural Affairs (DEFRA). 2015. "Affordability and Availability of Insurance - Final report FD2688”. DEFRA, London.

Department for Environment, Food and Rural Affairs (DEFRA). 2016a. "The Property Flood Resilience Action Plan". DEFRA, London. 
Department for Environment, Food and Rural Affairs (DEFRA). 2016b. “£700m boost for flood defences brings $£ 150 \mathrm{~m}$ more for Yorkshire and Cumbria”. DEFRA, London.

Department for Environment, Food and Rural Affairs (DEFRA) and Association of British Insurers (ABI). 2013. "Flood Re Proposal: Memorandum of Understanding”. DEFRA and $\mathrm{ABI}$.

Department for Environment, Food and Rural Affairs (DEFRA) and Environment Agency. 2013. "Delivering benefits through evidence - Benchmarking the latest generation of 2D hydraulic modelling packages)". Report SC120002.

Diacon, S. 2013. "Independent Review of Flood Insurance Analysis". Available at: https://consult.defra.gov.uk/flooding/floodinsurance/supporting_documents/FINAL\%20I ndependent\%20review\%20of\%20flood\%20insurance\%20analysis.pdf [accessed 10 October 2016].

Di Falco, S., F. Adinolfi, M. Bozzola and F. Capitanio. 2014. "Crop Insurance as a Strategy to Adapt to Climate Change". Volume 65 Issue 2 Journal of Agricultural Economics.

Direct Line Insurance PLC. 2016. "Half Year 2016 Earnings Call—Final”. Direct Line Insurance PLC.

Edgar, L. 10 July 2015. “Automatic planning permission for brownfield land”. The Planner. Available at: https://www.theplanner.co.uk/news/automatic-planning-permission-forbrownfield-land [accessed 2 November 2016].

Edmonds, T. 2016. "Household flood insurance”. House of Commons Library Briefing Paper Number 06613.

Ellis, C. 27 November 2014. "Flood victims 'struggling to cope' with soaring insurance bills". BBC News. Available at: http://www.bbc.com/news/uk-england-30115880 [accessed 2 November 2016].

Environmental Audit Committee. 2016. "Flooding: Cooperation across Government:

Government Response to the Committee's Second Report of Session 2016-17'. House of Commons, Environmental Audit Committee. Available at: https://publications.parliament.uk/pa/cm201617/cmselect/cmenvaud/645/645.pdf [accessed 6 November 2017].

Ermoliev, Y. M., T. Y. Ermolieva, G. J. Macdonald, V. I. Norkin, and A. Amendola (2000), A 
system approach to management of catastrophic risks, Eur. J. Oper. Res., 122, 452-460, doi:10.1016/S0377-2217(99)00246-5.

European Commission. 2013. "Green Paper on the Insurance of Natural and Man-Made Disasters”. COM (2013) 213 final [online]. European Commission: Strasbourg. Available at:

http://eurlex.europa.eu/LexUriServ/LexUriServ.do?uri=COM:2013:0213:FIN:EN:PDF [accessed 2 November 2016].

Flood Block. 2015. "What Flooding Really Costs". Flood Protection News. Available at: https://www.floodblockbarrier.com/flood-protection-news/what-flooding-really-costs/ [accessed 2 October 2016].

Flood Re. 2016a. “Annual Report and Financial Statements - Year ended 31 March 2016”. Flood Re. Available at: http://www.floodre.co.uk/wp-content/uploads/Flood-Re-AnnualReport-and-Financial-Statements-Yr-Ended-31-March-16-final-for-printing.pdf [accessed 10 October 2016].

Flood Re. 2016b. "The first Flood Re transition plan”. Flood Re. Available at: http://www.floodre.co.uk/wp-content/uploads/Flood-Re-Transition-Plan-Feb-2016FINAL..pdf [accessed 2 November 2016].

Flood Re. 2016c. "Eligibility”. Flood Re. Available at: http://www.floodre.co.uk/industry/howit-works/eligibility/ [accessed 10 October 2016].

Golnaraghi, M., S. Surminski and K.-U. Schanz. 2016. “An Integrated Approach to Managing Extreme Events and Climate Risks - Towards a Concerted Public-Private Approach". The Geneva Association. Available at https://www.genevaassociation.org/media/952146/20160908_ecoben20_final.pdf [accessed 5 November 2016].

Hallegatte, S. 2014. "Economic Resilience: definition and measurement". The World Bank. Hansard. 2011. HC Deb 19 December 2011 c141 Written Statement. House of Commons. Harries, T. 2012. “The Anticipated Emotional Consequences of Adaptive Behaviour - Impacts on the Take-up of Household Flood-Protection Measures". Volume 44 Issue 3 Environment and Planning A.

Herrington \& Carmichael Solicitors. 2009. "Flood Re. and Insuring Against Flood Damage”. Herrington and Carmichael Solicitors. Available at: http://www.herrington- 
carmichael.com/Documents/Articles/7ca8a013-5947-49cb-bd02-d01f4df65add.pdf

[accessed 5 October 2016].

Hjalmarsson, J (ed.). 2015. "Future directions of consumer flood insurance in the UK".

University of Southampton. Available at:

https://www.southampton.ac.uk/assets/imported/transforms/content-

block/UsefulDownloads_Download/5833464F560E457BBB32BE07A53B9419/58175_R

eport_v4_WEB.pdf [accessed 13 December 2016].

Hjalmarsson, J. and J. Davey. 14 January 2016. "Flagship plan to rescue flood-hit home owners already looks out of its depth". The Conversation. Available at:

http://theconversation.com/flagship-plan-to-rescue-flood-hit-home-owners-already-looksout-of-its-depth-52791.

HM Government. 2016. "National Flood Resilience Review”. HM Government.

Hoban, M. 2016. "Apres mon deluge: Flood Re as a response to large-scale climate risk". CII Thinkpiece no. 124. Available at: http://www.cii.co.uk/knowledge/policy-and-publicaffairs/articles/tp124-hoban-flood-re/40490 [accessed 10 October 2016].

Horn, D. and M. McShane. 2015. "Risk reduction in a changing insurance climate: examples from the US and the UK". EGU General Assembly 2015, held 12-17 April, 2015 in Vienna, Austria. id.14745.

Hornstein, D. 2015. "The insurance industry on the cusp of COP 21: lessons from insurance reform in the US and UK". In Hjalmarsson, J. (ed.). 2015. "Future directions of consumer flood insurance in the UK". University of Southampton. Available at: https://www.southampton.ac.uk/assets/imported/transforms/contentblock/UsefulDownloads_Download/5833464F560E457BBB32BE07A53B9419/58175_R eport_v4_WEB.pdf [accessed 13 December 2016].

House of Commons. 2013. "Flood insurance clauses Part 1 - Flood insurance". House of Commons. Available at: https://www.gov.uk/government/uploads/system/uploads/attachment_data/file/237133/flo odinsurance-clauses.pdf [accessed 10 December 2016].

House of Commons. 2016. "Oral evidence: Future Flood Prevention, HC 115”. House of Commons. 
Hudson, PGMB 2017, 'The Use of Insurance to Improve Flood Resilience', PhD, Vrije Universiteit Amsterdam.

Institute and Faculty of Actuaries. 2016. "The future of UK flood policy: Policy summary”.

Institute and Faculty of Actuaries. Available at: https://www.actuaries.org.uk/news-andinsights/media-centre/media-releases-and-statements/increased-spending-flood-defencesnot-enough-solve-flooding-problems [accessed 4 November 2016].

Insurance Newslink. 2016. "Flood Re now supported by 36 insurance providers representing $85 \%$ of the market". Insurance Newslink.

Interdepartmental Flood Policy Co-ordination Group. 2016. "Interim Report to Government". Available at: http://www.opw.ie/en/media/Interim-Report-Interdepartmental-FloodPolicy-Coordination-Group-final.pdf [accessed 8 November 2016].

Intergovernmental Panel on Climate Change (IPCC). 2013. "Fifth Assessment Report - Climate Change 2013”. Intergovernmental Panel on Climate Change.

JBA Risk Management. 2015. “JBA Risk Management Releases Comprehensive New UK Flood Model for Flood Re". JBA Risk Management Press Release. Available at: http://www.jbarisk.com/jba-risk-management-releases-comprehensive-new-uk-floodmodel-flood-re [accessed 2 November 2016].

Jenkins K., S. Surminski, J. Hall and F. Crick. 2017. "Assessing surface water flood risk and management strategies under future climate change: Insights from an Agent-Based Model”. Volume 595, Science of the Total Environment, 159-168.

Kenning, E. 31 January 2012. “ABI refuses to renew statement of principles for flood insurance". Insurance Age. Available at: https://www.insuranceage.co.uk/insuranceage/news/2142531/abi-refuses-renew-statement-principles-flood-insurance [accessed 3 November 2016].

Kingdon, J.W. 1995. “Agendas, alternatives, and public policies”. Harper Collings College: New York, NY.

Kunreuther, H. 1996. "Mitigating disaster losses through insurance”. Volume 12 Journal of Risk and Uncertainty, 171-187.

Kunreuther, H. and E. Michel-Kerjan. 2009. "Managing Catastrophes through Insurance:

Challenges and Opportunities for Reducing Future Risks”. Working Paper \# 2009-11-30. The Wharton School, University of Pennsylvania, Philadelphia. 
Kunreuther, H.C., E. O. Michel-Kerjan, N. A. Doherty, M. F. Grace, R. W. Klein, and

M. V. Pauly. 2009. At War with the Weather: Managing Large-Scale Risks in a New Era of Catastrophes. Cambridge, MA: MIT Press.

Lamond, J., D. Proverbs and F. Hammond. 2009. "Accessibility of flood risk insurance in the UK: confusion, competition and complacency”. Volume 12 Issue 6 Journal of Risk Research.

Lamond,J. and Penning-Rowsell, E. The robustness of flood insurance regimes given changing risk resulting from climate change, Climate Risk Management 2 (2014) 1-10.

Maccaferri, S., F. Cariboni and F. Campolongo. 2012. "Natural Catastrophes: Risk relevance and Insurance Coverage in the EU'. European Commission Joint Research Centre Scientific and Technical Reports.

Mechler, R., L.M. Bouwer, J. Linnerooth- Bayer, S. Hochrainer- Stigler, J.C.J.H. Aerts, S. Surminski, and K. Williges. 2014. "Managing unnatural disaster risk from climate extremes". Volume 4 Nature Climate Change.

Mysiak, J. and C.D. Pérez-Blanco. 2016. "Partnerships for disaster risk insurance in the EU". Volume 16 Issue 11 Natural Hazards and Earth System Sciences.

Oliver, R. 2016. "Use of big data risks making some people uninsurable”. Financial Times.

O’Neill, J. and M. O’Neill. 2012. "Social justice and the future of flood insurance”. Joseph Rowntree Foundation.

Oxera. 2015. "Why does it always rain on me? A proposed framework for flood insurance". Oxera. Available at: http://www.oxera.com/Latest-Thinking/Agenda/2015/Why-does-italways-rain-on-me-A-proposed-framework.aspx [accessed 10 October 2016].

Paudel, Y. 2012. “A Comparative Study of Public-Private Catastrophe Insurance Systems: Lessons from Current Practices”. Volume 37 Issue 2 The Geneva Papers on Risk and Insurance - Issues and Practice.

Pauly, M. 1968. “The Economics of Moral Hazard: Comment”. Volume 58 No. 3 The American Economic Review. 
Penning-Rowsell, E.C. and S.J. Priest. 2015. "Sharing the burden of increasing flood risk: who pays for flood insurance and flood risk management in the United Kingdom”. Volume 20 Issue 6 Mitigation and Adaptation Strategies for Global Change.

Penning-Rowsell, E.C., S.J. Priest and C. Johnson. 2014. "The evolution of UK flood insurance: incremental change over six decades". Volume 30 Issue 4 International Journal of Water Resources Development.

Prudential Regulation Authority. 2015. "The impact of climate change on the UK insurance sector: A Climate Change Adaptation Report by the Prudential Regulation Authority”. Prudential Regulation Authority, London. Available at: http://www.bankofengland.co.uk/pra/documents/supervision/activities/pradefra0915.pdf [accessed 10 October 2016].

Rittel, H.W.J. and M.M. Webber. 1973. "Dilemmas in a general theory of planning”. Volume 4 Issue 2 Policy Sciences.

Sandford, M. 2015. "The Bellwin Scheme". House of Commons Briefing Paper Number CBP00643.

Surminski, S. 2014. "The role of insurance in reducing direct risk: the case of flood insurance". LSE Research Online. Available at: http://eprints.lse.ac.uk/60764/1/Surminski_Role-ofinsurance-reducing-direct-risk_2014.pdf [accessed 15 October 2016].

Surminski, S. 2017. "Fit for the future? The reform of flood insurance in Ireland: resolving the data controversy and supporting climate change adaptation”. Grantham Research Institute on Climate Change and the Environment, Centre for Climate Change Economics and Policy.

Surminski, S. and Thieken, A. (2017) Promoting flood risk reduction: the role of insurance in Germany and England. Earth's Future. ISSN 2328-4277

Surminski, S. and P. Hudson. 2017. "Investigating the Risk Reduction Potential of Disaster Insurance Across Europe". Volume 42 Issue 2 The Geneva Papers on Risk and Insurance: Issues and Practice.

Surminski, S. and J. Eldridge. 2015. "Flood Insurance in England - An Assessment of the Current and Newly Proposed Insurance Scheme in the Context of Rising Flood Risk". 
Journal of Flood Risk Management.Surminski, S., J. Aerts, W. Botzen, P. Hudson, J. Mysiak and C. Pérez-Blanco. 2015. "Reflections on the current debate on how to link flood insurance and disaster risk reduction in the European Union”. Volume 79 Issue 3 Natural Hazards, 1451-1479.

Surminski, S. and D. Oramas-Dorta. 2014. "Flood insurance schemes and climate adaptation in developing countries”. Volume 7 International Journal of Disaster Risk Reduction.

Valuation Office Agency. 2017. "How domestic properties are assessed for Council Tax Bands". Valuation Office Agency. Available at: https://www.gov.uk/guidance/understand-howcouncil-tax-bands-are-assessed [accessed 9 July 2017]

Vivid Economics, Surminski Consulting and Callund Consulting. 2016. "Final Report: Understanding the role of publicly funded premium subsidies in disaster risk insurance in developing countries". Report prepared for UK DFID, London. Available at: http://www.evidenceondemand.info/understanding-the-role-of-publicly-funded-premiumsubsidies-in-disaster-risk-insurance-in-developing-countries [accessed 20 January 2017]

Yorkshire Evening Post. 27 March 2016. "South to get five times as much flood defence money as the North". Yorkshire Evening Post. Available at: http://www.yorkshireeveningpost.co.uk/news/south-to-get-five-times-as-much-flooddefence-money-as-the-north-1-7819311 [accessed 6 November 2017] 